\title{
GOMMENTS
}

\section{THE ACGOMMODATION OF "OCGUPATION" AND "SOCIAL UTILITY" IN PRIOR PUBLIC USE JURISPRUDENCE}

\author{
Mark S. ARENA $\dagger$
}

\section{INTRODUCTION}

The city of New Haven owns an airport located partially within the city and partially within the town of East Haven. East Haven is hostile to the development of the airport and for years has sought to contain it. East Haven and the East Haven Economic Development Commission institute eminent domain proceedings to take three parcels of the airport's land, situated in East Haven but owned by New Haven, to develop an industrial park. The parcels are not currently used for airport operations except to the extent that they ensure requisite unobstructed air space and permit future expansion of airport facilities. The industrial park could be an important source of economic development for the town. East Haven seeks to take the parcels subject to any height restrictions imposed by federal and state statutes and regulations. In response, the city of New Haven and the board of airport commissioners bring actions to enjoin East Haven from taking the three parcels. New Haven's central argument is that the property cannot be condemned because it is already devoted to public use. ${ }^{1}$

The prior public use doctrine is a judicial rule employed in the adjudication of such conflicts, in which a condemnor endowed with a general grant of the power of eminent domain attempts to use the power to take property already dedicated to a public use. The problem often arises in disputes between corporations granted equal powers of

† B.A. 1979, Ursinus College; M.A. 1981, University of Pennsylvania; J.D. Candidate 1989, University of Pennsylvania.

1 The facts are drawn from City of New Haven v. Town of E. Haven, 35 Conn. Supp. 157, 402 A.2d 345 (1977), affd, 177 Conn. 749, 419 A.2d 349 (1979); see also infra note 32 and accompanying text (discussing City of New Haven). 
eminent domain by the state. ${ }^{2}$ The state may delegate this power to political subdivisions such as counties and municipalities. ${ }^{3}$ In addition, despite the prevailing conception of eminent domain as a governmental attribute, the state may also delegate the power to private corporations furnishing public services, such as utility companies and railroads. ${ }^{4}$ The various political subdivisions enjoy equal stature "within their proper spheres." Moreover, these subdivisions, as public corporations, are generally considered to be of equal stature to private corporations endowed with the same power of eminent domain. ${ }^{6}$ Although the state may authorize the taking of land devoted to one public use for a different public use, statutes conferring the power of eminent domain to public and private corporations often fail to address the question whether or not the entity may condemn property already dedicated to public use. ${ }^{7}$ This situation has spawned the prior public use doctrine.

The rule may be set forth briefly, for the articulation of its essential elements varies little from one jurisdiction to another, and courts often recite as well-settled the standard renditions propounded in the treatises. For example:

"[When a] condemnor to whom the power of eminent domain has been delegated, such as a municipality or a private corporation, seeks to exercise the power with respect to property already devoted to public use, the general rule is that where the proposed use will either destroy such existing use or interfere with it to such an extent as is tantamount to destruction, the exercise of the power will be denied unless the legislature has authorized the acquisition either expressly or by necessary implication."

2 See infra notes 5-16 and accompanying text.

3 See R. Gunningham, W. Stoebuck \& D. Whitman, The Law of PropERTY 510 (1984) [hereinafter R. Cunningham]; Dau, Problems in Condemnation of Property Devoted to Public Use, 44 TEx. L. REv. 1517, 1520 (1966).

- See R. Cunningham, supra note 3, at 510; Dau, supra note 3, at 1520.

- Dau, supra note 3, at 1520.

- See id.

7 See id. at 1521.

${ }^{8}$ Greater Clark County School Corp. v. Public Serv. Co., 179 Ind. App. 331, 333, 385 N.E.2d 952, 954 (1979) (quoting 1 P. Nichols, The LAW of EMINENT Domain $\S 2.2$, at $2-57$ to $2-58$ (rev. $3 \mathrm{~d}$ ed. 1973 )). Another very similar, frequently encountered version reads:

The general rule . . . is that ". . . property already devoted to a public use cannot be taken for another public use which will totally destroy or materially impair or interfere with the former use, unless the intention of the legislature that it should be so taken has been manifested in express terms or by necessary implication, mere general authority to exercise the power of eminent domain being in such case insufficient; . . . ." 
The doctrine has been invoked to resolve such conflicts as a city's attempt to condemn, for erection of a water tower, the land of a cemetery association; ${ }^{9}$ a town's attempt to condemn, for development of an industrial park, airport property owned by a city; ${ }^{10}$ a city's attempt to condemn, for airport operation, easement rights in the airspace of property owned by a railroad; ${ }^{11}$ a state highway commission's attempt to condemn township park property; ${ }^{12}$ a township's attempt to condemn, for recreational and parking facilities, land owned by a railroad; ${ }^{\mathbf{1 3}}$ a city's attempt to condemn, for construction of an airport, the public street of a village; ${ }^{14}$ a city's attempt to condemn and take over the operation of a public utility's electrical facilities; ${ }^{15}$ and a city's attempt to condemn the land of a charitable hospital in order to widen a street. ${ }^{16}$

Although courts have concurred in their characterization of the prior public use doctrine, they have diverged in their interpretation and application of the rule. The rule raises a number of questions: What is "use"? What is "public use"? When are uses "compatible"? What con-

Tuomey Hosp. v. City of Sumter, 243 S.C. 544, 549, 134 S.E.2d 744, 746 (1964) (quoting 29 C.J.S. Eminent Domain $\S 74$, at 861). For additional statements of the rule, see, e.g., Beth Medrosh Hagodol v. City of Aurora, 126 Colo. 267, 273, 248 P.2d 732, 735 (1952) (en banc); City of New Haven v. Town of E. Haven, 35 Conn. Supp. 157, 164, 402 A.2d 345, 349 (1977), affd, 177 Conn. 749, 419 A.2d 349 (1979); City of Wilmington v. Lord, 340 A.2d 182, 184 (Del. Super. Ct. 1975); Florida E. Coast Ry. v. Broward County, 421 So. 2d 681, 683 (Fla. Dist. Ct. App. 1982); Michigan State Highway Comm'n v. St. Joseph Township, 48 Mich. App. 230, 238-39, 210 N.W.2d 251, 255-56 (1973); Kansas City v. Ashley, 406 S.W.2d 584, 589 (Mo. 1966); Township of Weehawken v. Erie R.R., 20 N.J. 572, 579, 120 A.2d 593, 596 (1956); E \& J Holding Corp. v. Noto, 126 A.D.2d 641, 642, 510 N.Y.S.2d 899, 901 (1987); Southern Ry. v. City of Greensboro, 247 N.C. 321, 329, 101 S.E.2d 347, 355 (1957); Yadkin County v. City of High Point, 217 N.G. 462, 465, 8 S.E.2d 470, 472 (1940); Village of Blue Ash v. City of Cincinnati, 173 Ohio St. 345, 351, 182 N.E.2d 557, 56162 (1962); Village of Richmond Heights v. Board of County Comm'rs, 112 Ohio App. 272, 280, 166 N.E.2d 143, 150 (1960), appeal dismissed per curiam, 171 Ohio St. 449, 172 N.E.2d 133 (1961); City of Brook Park v. Columbia Rd. Inv., Inc., 23 Ohio Misc. 363, 365-66, 256 N.E.2d 284, 286 (P. Ct. 1970); City of Pryor Creek v. Public Serv. Co., 536 P.2d 343, 346 (Okla. 1975); President and Fellows of Middlebury College v. Central Power Corp., 101 Vt. 325, 336, 143 A. 384, 388 (1928); Vermont Hydro-Elec. Corp. v. Dunn, 95 Vt. 144, 149, 112 A. 223, 225 (1921); 2A C. ANTIEAU, Municipal Corporation LaW $\S 20.01$ (D. Epstein rev. ed. 1984); Ball, Intergovernmental Conflicts in Land Acquisition: Adjustment for Maximum Public Benefit, 10 OHIo ST. L.J. 30, 33-34 (1949); Dau, supra note 3, at 1521.

${ }^{\circ}$ See Beth Medrosh Hagodol, 126 Colo. at 267, 248 P.2d at 732.

${ }^{10}$ See City of New Haven, 35 Conn. Supp. at 157, 402 A.2d at 345.

"See Florida E. Coast Ry., 421 So. 2d at 681. 251.

${ }^{12}$ See Michigan State Highway Comm'n, 48 Mich. App. at 230, 210 N.W.2d at

13 See Township of Weehawken v. Erie R.R., 20 N.J. 572, 120 A.2d 593 (1956).

14 See Village of Blue Ash v. Gity of Cincinnati, 173 Ohio St. 345, 182 N.E.2d 557 (1962).

${ }^{15}$ See City of Pryor Creek v. Public Serv. Co., 536 P.2d 343 (Okla. 1975).

18 See Tuomey Hosp. v. City of Sumter, 243 S.C. 544, 134 S.E.2d 744 (1964). 
stitutes "necessary implication"? What is the appropriate judicial role contemplated by the doctrine? Courts have not always resolved these issues consistently. ${ }^{\mathbf{1 7}}$

Part I of this Comment analyzes the variations in judicial interpretation and application of the prior public use doctrine. In so doing, it demonstrates the following theses:

1. Courts usually recite the rule mechanically, without analyzing its purpose, and, when they do offer reasons for it, they perfunctorily describe it as a means of implementing legislative intent or averting circular condemnations.

2. Courts consistently construe the term "use," in the phrase "property already devoted to public use," liberally enough to encompass not only current use, but also reasonably anticipated future use, so long as the expectation of use is not merely an indefinite, "naked" possibility.

3. Courts have revealed a tension, in construing the term "public use," between a) a bright line rule that formalistically requires the resisting owner to possess a power of condemnation equivalent to that of the condemnor and b) a more flexible, case-by-case approach.

4. The "compatible use" theory permits a taking if the proposed and pre-existing uses may exist together, even if the pre-existing user may suffer some inconvenience.

5. Authorities conflict over the degree of necessity required by the words "unless the legislature has authorized the acquisition by necessary implication." Some authorities look for a necessity so absolute that a denial of the acquisition would defeat the grant of power; other authorities consider factors of practicality and economy and look only for reasonable necessity.

6. Some courts embrace a "more necessary use" test, weighing the benefits to the public of the competing uses, while other courts refuse to engage in the weighing process. Among the former courts, the test has assumed a variety of forms, such as a) an exception to the prior public use rule; b) a narrowly drawn embodiment of the exception, requiring that the necessity be so great as to make the new enterprise of paramount importance to the public and that the enterprise cannot be accomplished practically in any other way; and c) an application of broad "more necessary use" statutory provisions.

7. Some courts attribute great significance to the "character" of condemnor and condemnee, such that a) a municipal corporation may condemn the facilities of a public service corporation to take over their

17 See infra notes $26-105$ and accompanying text. 
operation or b) the protection of the prior public use doctrine is inoperative when an agent of the state seeks to condemn land devoted to public use. Other courts, however, do not discriminate in this manner when applying the doctrine.

Part II of the Comment suggests a prior public use jurisprudence that reconciles the divergent applications of the doctrine. Drawing on two theories frequently advanced to justify property ownership, it argues that the best rationale for the doctrine is its potential for accommodating both the "occupation" and "social utility" dimensions of property. The appropriate judicial role contemplated by the doctrine derives from courts' ability, and duty, to be responsive to both dimensions of property in prior public use adjudication. The principle of judicial protection of possession or occupation, tempered by judicial mindfulness that it is desirable to use property in the most socially valuable way, points to a solution of the conflicts engendered by the "necessary implication" clause and the various incarnations of the "more necessary use" test. Furthermore, this principle furnishes guidance to the courts in construction of the term "public use" and indicates the degree of significance courts should attribute to the "character" of the condemnor and the condemnee.

\section{JUdicial Interpretation AND Application of the DOCTRINE}

\section{A. Reasons for the Rule}

An unfortunate feature of the prior public use doctrine is that it has assumed a talismanic stature that precludes many courts from inquiring into its policy justifications. The rule is invoked with enough metronomic uniformity to vindicate the comment that "even the most devoted rule-fetishist would like to have a glimmer as to the reasons we have the rules we have."18 When courts have paused to reflect on the reasons for the prior public use doctrine, their reflections have been perfunctory, so that the cases advance the same rationales with a regularity matching that of the repetition of the rule itself.

One explanation views the doctrine as a means of effectuating legislative intent: the sovereign, in delegating the power of eminent domain to municipal or private corporations, could not intend that the public use of one be subject to destruction, through condemnation, by the public use of another, because both uses have been authorized by

18 B. Ackerman, Private Property and the Constitution 8 (1977). 
the sovereign. ${ }^{19}$ As one court stated:

"[I]t could not be intended that the state, having authorized one taking, whereby the lands became impressed under authority of the sovereign with a public use, meant to nullify its own grant by authority to another corporation to take them again for another public use, unless it so specifically decreed ...."20

As Part II of this Comment shows, this argument ignores both the limitations of the legislative process and the context in which clashes between public uses arise. ${ }^{21}$

A second explanation-by far the most frequently encountered-conceives of the doctrine as a means to avert circular, recriminatory, or serial condemnations. Many corporations, both private and municipal, are endowed with general powers of condemnation. Thus, the argument goes, if one may condemn the land of another under such a general power, then the latter "would logically be free to reacquire the same property" from the former. ${ }^{22}$ One court noted that, absent a

19 See Hiland v. Ives, 154 Conn. 683, 689-90, 228 A.2d 502, 505 (1967).

20 Board of Educ. v. Pace College, 27 A.D.2d 87, 89, 276 N.Y.S.2d 162, 165 (1966) (quoting In re New York, L. \& W. R.R., 99 N.Y. 12, 23, 1 N.E. 27, 32 (1885)), motion denied, 19 N.Y.2d 672, 225 N.E.2d 554, 278 N.Y.S.2d 862 (1967); see also Note, The Sovereign's Duty to Compensate for the Appropriation of Public Property, 67 Colum. L. REv. 1083, 1086 (1967) ("The doctrine presumes that the legislature does not intend to terminate other public uses of property when it delegates a general power to take.").

${ }^{21}$ See infra notes 136-37 and accompanying text.

22 Township of Weehawken v. Erie R.R., 20 N.J. 572, 579, 120 A.2d 593, 596 (1956); see also Denver Power \& Irrigation Co. v. Denver \& R.G. R.R., 30 Colo. 204, 212,69 P. 568, 571 (1902) ("[T]here would be no reasonable limit to the conditions under which the power of eminent domain might be exercised."); Florida E. Coast Ry. v. City of Miami, 321 So. 2d 545, 548 (Fla. 1975) (quoting Weehawken); Greater Clark County School Corp. v. Public Serv. Co., 179 Ind. App. 331, 333-34, 385 N.E.2d 952, 954 (1979) ("[A]bsent the prior public use rule, the land could be condemned back and forth indefinitely."); Louisiana Power \& Light Co. v. City of Houma, 229 So. 2d 202, 206 (La. Ct. App.) ("II]f under such authority the first taking would be justified, its retaking would be equally within the power of the adverse party."), cert. denied, 254 La. 1165, 229 So. 2d 350 (1969); City of Shakopee v. Clark, 295 N.W.2d 495, 500 (Minn. 1980) ("Prevention of this type of spectacle of two entities granted the right of eminent domain condemning each other's land is perhaps the primary reason for the prior public use doctrine."); County of Bergen v. Erie Lackawanna R.R., 81 N.J. Super. 344, 348, 195 A.2d 511, 513 (Law Div. 1963) ("[A] wasteful circuitry of litigation would result ...."), aff'd sub nom., Joint Meeting No.1 v. Erie Lackawanna R.R., 43 N.J. 281, 204 A.2d 129 (1964); Matteoni, The California Roadway- "A More Necessary Public Use", 20 HAstings L.J. 551, 553 (1969) (describing the prior public use doctrine as "a limitation developed by the judiciary to prevent arbitrary or retaliatory acquisitions by authorized condemning agencies against one another"); Case Comment, Prior Public Use Doctrine: New Judicial Criteria-Florida East Coast Ry. v. City of Miami, 5 Fla. ST. U.L. REv. 505, 505-06 (1977) [hereinafter New Judicial Criteria] (stating that the doctrine "prevents the per- 
deterrent such as the prior public use doctrine, "[ $t]$ he logical implication would be that there is no secure or permanent dedication to any public use."2s Another court envisioned a parade of horrors in which " "the city might condemn the court house square for an engine house, the school district might condemn the engine house for a school house, the county might condemn the school house for a court house, and an endless chain of condemnations . . . might be set in operation." "24 $\mathrm{Al}$ though these concerns are no doubt valid, their rote repetition, combined with the reductio ad absurdum, has rendered them somewhat insubstantial; theoretically logical implications are of little use to courts presented with real clashes between public uses. Moreover, as Part II of this Comment argues, the threat of circular condemnations is easily dispelled. $^{25}$

\section{B. The Nature of "Use"}

The question of what constitutes "use" arises because the rule protects from condemnation only property that is "already devoted to public use." Consequently, a condemnor may try to demonstrate that the disputed land is not being used. Courts have defined the criteria for "use" consistently, often drawing on the language of Vermont HydroElectric Corp. v. Dunn. ${ }^{28}$ In that case, the Vermont Supreme Court liberally construed the term "use" to encompass not only current use, but also reasonably anticipated future use: "[I]t is not necessary that the property be actually in use for the public purpose to exempt it from the proceeding." ${ }^{27}$ The court took pains, however, to limit its liberal construction of "use" by imposing a reasonableness test. The rule would not exempt property "held for future use upon the mere possibility that it may at some future time become necessary . . . . Reasonable expectation of future needs is required .... Nor is the exemption indefinite in point of time, but the property must be subjected to . . . use . . . within a reasonable time. ${ }^{28}$ As the New Jersey Supreme Court has put it, the doctrine "applies to land held by a corporation to accommodate reasonably foreseeable future demands, . . . although a

petuation of condemnation proceedings").

${ }^{23}$ Cemetery Co. v. Warren School Township, 236 Ind. 171, 185, 139 N.E.2d 538, 544-45 (1957).

${ }^{24}$ Medical Center Comm'n v. Powell, 124 Ill. App. 2d 123, 131, 260 N.E.2d 261, 265 (1970) (quoting City of Edwardsville v. County of Madison, 251 Ill. 265, 267, 96 N.E. 238,238 (1911)).

${ }^{25}$ See infra notes 163-64 and accompanying text.

2895 Vt. 144, 112 A. 223 (1921).

${ }^{27} \mathrm{Id}$. at $149,112 \mathrm{~A}$. at 226.

${ }^{28} I d$. at 150,112 A. at 226 (citations omitted). 
mere naked possibility that it will be so used will not immunize it 9329

The Michigan Court of Appeals held that the foregoing principles precluded a township from bringing its "park land" within the ambit of the rule when the property had not been used by the public in the eight years since its dedication to park purposes, no public money had been appropriated for the "park", the township could not demonstrate a need for the particular land at issue instead of the land offered by the condemnor in exchange, and there was only a possibility that the land would be used by the public in the future. ${ }^{30}$ Similarly, the "mere laying of rails" by a railroad company across a right of way that had been held idle by several railroad companies for approximately sixteen years did not manifest a "bona fide intention" to devote the way to railroad use-especially considering that the action was taken shortly before the commencement of condemnation proceedings by a power company, which wanted the land for a reservoir site. ${ }^{31}$ On the other hand, when a town sought to condemn parcels of airport land owned by a neighboring city, but located within the town, the land was insulated from condemnation by the Connecticut Superior Court, even though it was not being used for actual airport operations at the time, because "it is reasonable to conclude that there will be an increase in the demand for the services of the airport . . . These increases . . . will require the expansion of the airport facilities. Accordingly, it is anticipated that the

${ }^{29}$ Township of Weehawken v. Erie R.R., 20 N.J. 572, 583, 120 A.2d 593, 598 (1956) (citations omitted); see also East Bay Mun. Util. Dist. v. City of Lodi, 120 Cal. App. 740, 754, 8 P.2d 532, 537 (1932) ("[T]here must be a liberal consideration of the future, . . . but the mere possibility that the land . . . may at some future time become necessary" is not sufficient.); Denver Power \& Irrigation Co. v. Denver \& R.G. R.R., 30 Colo. 204, 218, 69 P. 568, 572 (1902) (The condemned lands "must, within a reasonable time, be subjected to the use for which they were granted."); City of New Haven v. Town of E. Haven, 35 Conn. Supp. 157, 169, 402 A.2d 345, 352 (1977) ("The test must be whether there is a reasonable assurance that the intended use will come to pass."), affd, 177 Conn. 749, 419 A.2d 349 (1979); Dau, supra note 3, at 1517 ("WW]hile it is not necessary for the property to be actually in use for the public purpose, the intent to place the property into this use without unreasonable delay must be present."); Matteoni, supra note 22, at 561 ("Property acquired by a condemnor for public use and held in reasonable anticipation of future needs with a bona fide intention of using it for such public purpose within a reasonable time is 'appropriated to' a public purpose.").

so See Michigan State Highway Comm'n v. St. Joseph Township, 48 Mich. App. 230, 240, 210 N.W.2d 251, 256 (1973).

${ }^{31}$ See Denver Power, 30 Colo. at 218-19,69 P. at 573; cf. County of Bergen v. Erie Lackawanna R.R., 81 N.J. Super. 344, 348, 195 A.2d 511, 513 (Law Div. 1963) (stating that the mere filing of a condemnation complaint does not devote the land sought to public use), aff'd sub nom., Joint Meeting No.1 v. Erie Lackawanna R.R., 43 N.J. 281, 204 A.2d 129 (1964). 
land ... will be used ... within the reasonably foreseeable future "32

\section{G. The Nature of "Public Use"}

"Use" alone does not trigger the prior public use doctrine; the use must qualify as a "public use." To determine whether a given use qualifies as a public use, courts have struggled with conflicting impulses: on the one hand, there is the safety of a bright-line rule; on the other hand, some cases lend themselves to a more flexible, case-by-case approach. The language of Vermont Hydro-Electric has again struck a chord that has resonated over the years, expressing the rule as follows:

[A] mere voluntary assumption of public service which may be abandoned at any time does not carry with it the privilege of exemption. The test whether land is held for a public use such as will exempt it from condemnation is said not to be what the owner does or may choose to do but what under the law he must do, and whether a public trust is impressed upon it. $^{33}$

This type of "test" appears in a host of opinions from courts of other states. ${ }^{34}$ Some courts have applied it with relentless rigor. For example, the Missouri Court of Appeals concluded that when a water company had not reached "the point where [it was] under a present legal obligation to maintain a public purpose," it "simply had not done enough to omitted).

32 City of New Haven, 35 Conn. Supp. at 169, 402 A.2d at 352 (footnotes

ss Vermont Hydro-Elec., 95 Vt. at 149, 112 A. at 226.

s4 See, e.g., City of New Haven, 35 Conn. Supp. at 165, 402 A.2d at 350 ("The test . . . is not how the use is furnished but rather the right of the public to receive and enjoy its benefit."); President \& Fellows of Middlebury College v. Central Power Corp., 101 Vt. 325, 337, 143 A. 384, 388 (1928) ("It is essential to a public use, as the term is used in proceedings involving the law of condemnation or eminent domain, that the public must, to some extent, be entitled to use or enjoy the property, not by favor, but as a matter of right."); Bailey v. Anderson, 182 Va. 70, 74, 27 S.E.2d 914, 916 ("The test of whether or not property has been devoted to public use is what the owner must do, not what he may choose to do." (quoting 18 AM. JUR. Eminent Domain \$ 94, at 720)), cert. denied, 321 U.S. 799 (1943); 1 P. Nichols, supra note 8, $\S 2.2[5]$, at 2-86 ("If [the owner of land] has devoted it to a public use which he is under a legal obligation to maintain, it falls within the protection of the rule. On the other hand, a mere voluntary assumption of public service which may be abandoned at any time carries with it no such privilege."). But see Louisiana Power \& Light Co. v. Gity of Houma, 229 So. 2d 202, 210 (La. Ct. App.) ("That [the public] use may be discontinued at any time is a matter of no moment."), cert. denied, 254 La. 1165, 229 So. 2d 350 (1969); McCarter, The Case That Almost Was, 54 A.B.A. J. 1076, 1078 (1968) (claiming that the standard set forth in Vermont Hydro-Electric does not "bear scrutiny"). 
become a protected entity."36 The Supreme Court of Maine found that, although the activities of an agricultural society conferred some benefit upon the public, they "fell short of constituting 'public uses' in the technical sense": the society was a private, voluntary corporation, not a political subdivision of the state; it could be dissolved at any time; and its members were under no legal obligation to perpetuate the activities benefitting the public. ${ }^{38}$

In other cases, however, even as the courts pay lip service to the bright-line rule, they strive to loosen its constraints, often under the guise of liberal construction. For example, in Tuomey Hospital v. City of Sumter, ${ }^{37}$ in which the city sought to condemn land owned by an eleemosynary corporation operating a charitable hospital, the court endorsed the conventional dogma that "mere benefit" to the public does not constitute a public use; the public must have an "enforceable right to a definite and fixed use of the property."38 The court also acknowledged, however, the difficulty of comprehensively defining the term "public use," because the public-private distinction "lies in the character of the use and must to a large extent depend upon the facts of each case." ${ }^{39}$ The court concluded:

While the question of whether the complaint alleges a public use of the property involved is a close one, we think that under a liberal construction thereof, the question of public use is a factual issue which must be resolved, in the light of the foregoing principles, under the facts as developed upon the trial of the case. ${ }^{40}$ 1984).

3s City of Blue Springs v. Central Dev. Ass'n, 684 S.W.2d 44, 50 (Mo. Ct. App.

s8 Oxford County Agricultural Soc'y v. School Admin. Dist. No. 17, 161 Me. 334, 335-36, 211 A.2d 893, 894 (1965).

${ }_{37} 243$ S.C. 544,134 S.E.2d 744 (1964).

38 Id. at 551, 134 S.E.2d at 747 ("Mere benefit to the public or permission by the owner for use of property by the public are not enough to constitute a public use, but it must appear that the public has an enforceable right to a definite and fixed use of the property." (citing 29 C.J.S. Eminent Domain § 31; 18 AM. JuR. Eminent Domain \& 94 , at 720$)$ ).

${ }_{38}$ Id.

to Id. at 552, 134 S.E.2d at 748; see also City of New Haven, 35 Conn. Supp. at $165,402 \mathrm{~A} .2 \mathrm{~d}$ at 350 (" A public use defies absolute definition, for it changes with varying conditions of society .... Courts as a general rule, instead of attempting judicially to define a public as distinguished from a private purpose, have left each case to be determined on its peculiar circumstances. . . The modern trend of authority is to expand and liberally construe the meaning of "public purpose." " (quoting Barnes v. City of New Haven, 140 Conn. 8, 15, 98 A.2d 523, 527 (1953))), affd, 177 Conn. 749, 419 A.2d 349 (1979); President \& Fellows of Middlebury College v. Central Power Corp., 101 Vt. 325, 336, 143 A. 384, 388 (1928) (The private-public use distinction "cannot be made upon consideration of legal principles alone; economic condi- 
Another approach to the meaning of "public use" is to look not for a legal obligation on the owner's part, but rather, even more formalistically, at the mere status or nature of the owner. In one example, a city sought to condemn a water system located within an area of a township that had been annexed by the city. ${ }^{\mathbf{1 1}}$ The Kansas Supreme Court reasoned that the township had lost its legal authority to serve the public and that its property had been metamorphosed into private property held in a proprietary capacity. Therefore, the court concluded in a triumphant rhetorical question, "What now becomes of the argument that the township water system . . . is 'devoted to public use'? . . [O]ne public utility may condemn the property of another public utility if the last company is not using its property to serve the public."42 And in Board of Education v. Pace College, ${ }^{43}$ the New York Supreme Court, Appellate Division, held that a private institution of higher learning could not invoke the prior public use doctrine to resist a local school board's condemnation of its land, because the college did not possess a power to condemn equivalent to that of the condemnor. ${ }^{44}$ Its analysis of the case law convinced the court that:

Not one of the cited decisions contains the slightest suggestion that the law protects from condemnation for public purposes lands other than those "actually held by authority of the sovereign power for or necessary to some public purpose or use"....

. . . [W]e are persuaded that it is no defense to plaintiff's petition that Pace College performs an admittedly useful service to the community and one in which the public has such vital interest that the State undertakes to regulate and control closely those institutions which engage therein. ${ }^{45}$

In so ruling, the court reversed a decision below that had denied the susceptibility of "public use" to precise definition and had embarked on

tions and the needs of the people must have attention."). (1960).

11 See State ex rel. Foster v. City of Kansas City, 187 Kan. 286, 356 P.2d 859

${ }^{42} I d$. at $289-90,356$ P.2d at 861 .

4s 27 A.D.2d 87, 276 N.Y.S.2d 162 (1966), motion denied, 19 N.Y.2d 672, 225

N.E.2d 554, 278 N.Y.S.2d 862 (1967).

14 See id. at 89, 276 N.Y.S.2d at 164.

45 Id. at 90-91, 276 N.Y.S.2d at 165-66 (quoting In re Rochester Water Comm'rs, 66 N.Y. 413, 418 (1876)); see also Texas E. Transmission Corp. v. Wildlife Preserves, Inc., 48 N.J. 261, 268, 225 A.2d 130, 134 (1966) ("[Defendant] has no . . . power to acquire [its] lands . . by condemnation .... Under these circumstances, we are satisfied that [it] is not qualified under the prior public use doctrine . . . ."). 
an ad hoc examination of Pace College's nexus with the state educational system. ${ }^{46}$ The lower court had also noted that Pace College had the power to condemn real property for its water works and sewer system, thereby clothing such property in the public use garb. The court wryly pointed out the incongruity of a rule of law that would insulate from condemnation property "devoted to the purely service and incidental functions of water supply and sewerage disposal" while "rendering vulnerable ... the property and facilities devoted to its primary function, i.e., higher education." ${ }^{37}$

The prior public use jurisprudence proposed in Part II of this Comment stresses an accommodation of both the "occupation" and "social utility" dimensions of property. This Comment rejects bright-line formalism and embraces the more flexible, case-by-case approach. The rigid requirement that the condemnee be legally obligated to maintain a public purpose begs the essential question of what constitutes a public purpose. Neither this requirement nor the requirement that the resisting owner possess a power of eminent domain like that of the condemnor advances the twin goals of "occupation" and "social utility."48

\section{The "Compatible Use" Theory}

A further question arising under the prior public use doctrine derives from the requirement that the proposed use either destroy or materially impair the pre-existing use. This requirement has spawned an exception to the rule known as the "compatible use theory." Under the compatible use theory, the taking is permitted if the proposed use "will not materially impair or interfere with or is not inconsistent with the use already existing . . . "49 This exception has been characterized as

${ }^{46}$ See Board of Educ. v. Pace College, 50 Misc. 2d 806, 807-08, 271 N.Y.S.2d 773, 775-77 (Sup. Ct.), rev'd, 27 A.D.2d 87, 276 N.Y.S.2d 162 (1966), motion denied, 19 N.Y.2d 672, 225 N.E.2d 554, 278 N.Y.S.2d 862 (1967).

47 Id. at 810,271 N.Y.S.2d at 778 .

$48 \mathrm{Cf}$. infra notes 170-86 and accompanying text (discussing the significance of the character of the condemnor and condemnee).

49 Georgia S. \& Fla. Ry. v. State Rd. Dep't, 176 So. 2d 111, 112 (Fla. Dist. Ct. App. 1965); see also Florida E. Coast Ry. v. Broward County, 421 So. 2d 681, 683 (Fla. Dist. Ct. App. 1982) ("[W]hen a taking will not materially impair or interfere with or is not inconsistent with the existing use, and the proposed use is not detrimental to the public, then a court possesses authority to order a taking of the property."); Harrison County School Bd. v. State Highway Comm'n, 284 So. 2d 50, 53 (Miss. 1973) (permitting "one superior governmental body to condemn property of some other inferior governmental body if the taking will not materially impair the existing uses and is not detrimental to the public interest"); Village of Amityville v. Suffolk County, 132 N.Y.S.2d 845, 846 (N.Y. Sup. Ct. 1954) ("[W]here the new use is not inconsistent with the old use, one municipality may condemn the land of another municipality."); D. Mandeliker, D. Netsch \& P. Salsich, State and Local Government in a 
one of the means by which a court can circumvent the potentially excessive inhibitory effect of the rule-its "frightening inflexibility" - while preserving the rule's policy justification "that an important public use should be protected." Und Under the exception, it is no bar to condemnation that the pre-existing use may suffer some inconvenience, so long as the two uses may stand together..$^{62}$ The determination whether the two uses may stand together is to be made not "with reference to every possible manner in which the land might be used for the purpose for which it had been acquired, but with a reasonable regard to the way in which it would naturally and reasonably be used in putting it to that purpose." ${ }^{\text {"33 }}$ The compatible use theory has permitted a state road department to widen a road by condemning portions of a railroad company's right of way used for drainage, ${ }^{54}$ a state highway commission to condemn for construction of an interstate highway part of a school board's land used for recreational purposes, ${ }^{55}$ a county to condemn a right of way for a highway through a village's parking field, ${ }^{56}$ a town to lay out a street over land in which a city had laid its water pipes, ${ }^{57}$ and a gas and electric corporation to take an easement for placement of poles carrying overhead lines and conduits carrying

Federal System 161 (2d ed. 1983) [hereinafter D. MaNdelKer] ("[D]octrine permits intergovernmental condemnation when the proposed use would not interfere with or be inconsistent with the public use to which the property is presently devoted."); 11 E. McQuillin, The Law of Municipal Corporations $\S 32.72$ at 413 (3d ed. 1983) ("II]f the taking does not impair or interfere with the public use and is not inconsistent therewith, the property may be condemned."); Ball, supra note 8, at 35 ("If the court finds the uses consistent, taking will be allowed under general authority to the extent necessary to accommodate both uses."); Dau, supra note 3, at 1524 (when a new use can be carried on without materially impairing an established use, prior public use doctrine is inapplicable); Phay, The Municipal Corporation and Conflicts Over Extraterritorial Acquisitions: The Need for Land Planning, 17 VAND. L. REv. 347, 352 (1964) ("[G]ourts have . . . permitted a condemnation of publicly used property if the taking is consistent with the property and will not interfere with the present public use."); New Judicial Criteria, supra note 22, at 509 (recognizing a "compatible use" exception to prior public use doctrine).

so Phay, supra note 49 , at 367.

81 New Judicial Criteria, supra note 22, at 509.

62 See State v. T.O.L., Inc., 206 So. 2d 69, 73 (Fla. Dist. Ct. App. 1968).

s3 Gity of Boston v. Inhabitants of Brookline, 156 Mass. 172, 176, 30 N.E. 611, 611 (1892) (citing Inhabitants of Springfield v. Connecticut River R.R., 58 Mass. (4 Cush.) 63 (1849)); see also 11 E. MCQuILlin, supra note 49, § 32.68 (using virtually identical language to state the same standard).

${ }^{4}$ See Georgia S. \& Fla. Ry. v. State Rd. Dep't, 176 So. 2d 111 (Fla. Dist. Ct. App. 1965).

SS See Harrison County School Bd. v. State Highway Comm'n, 284 So. 2d 50 (Miss. 1973). 1954).

${ }^{58}$ See Village of Amityville v. Suffolk County, 132 N.Y.S.2d 845 (N.Y. Sup. Ct.

${ }^{\mathrm{B}}$ See City of Boston, 156 Mass. at 172, 30 N.E. at 611. 
underground lines in property owned by a railroad company. ${ }^{58}$

\section{E. The "Necessary Implication" Clause and the "More Necessary Use" Test}

\section{The Necessary Implication Glause}

A wrinkle in the prior public use doctrine that has engendered more widely disparate results is the "necessary implication" clause. This clause allows the taking of property devoted to public use if the legislature has authorized the taking by necessary implication. ${ }^{89}$ As one commentator has pointed out, authorities conflict over the degree of necessity needed to create the implication: some cases require the necessity to be so absolute that "the denial thereof would defeat the grant of the power," while other cases "hold that the factors of practicability and economy may be considered and that a reasonable necessity . . . will be sufficient to justify the exercise of the power."

${ }^{68}$ See Long Island R.R. v. Long Island Lighting Co., 103 A.D.2d 156, 165-66, 479 N.Y.S.2d 355, 362 (1984) ("LILCO is seeking to appropriate a limited interest in the property for a use not inconsistent with the use thereof by the railroad and it has successfully fashioned its taking so that the proposed condemnation comes within an exception to the . . . prior public use doctrine."), affd, 64 N.Y.2d 1088, 479 N.E.2d 226, 489 N.Y.S.2d 881 (1985).

${ }^{59}$ That same clause also allows the taking if the legislature has expressly authorized it. Express authorization is not litigated often, but for cases addressing the issue, see, e.g., City of E. Peoria v. Group Five Dev. Co., 87 Ill. 2d 42, 46, 429 N.E.2d 492, 494 (1981) ("In light of the amendments allowing just compensation for the taking of public property, it seems clear that the legislature intended to provide for the condemnation of property already devoted to a public use."); Louisiana Power \& Light Co. v. City of Houma, 229 So. 2d 202, 207 (La. Ct. App.) ("[F]or such authority to be expressly conferred, the statute must employ or include either the term 'public property' or some clear equivalent thereof."), cert. denied, 254 La. 1165, 229 So. 2 d 350 (1969); cf. City of Thornton v. Farmers Reservoir \& Irrigation Co., 194 Colo. 526, 537, 575 P.2d 382, 391 (1978) (en banc) (The Colorado constitution "grants to home rule municipalities ample power to acquire by condemnation property already devoted to a public use."); Beth Medrosh Hagodol v. City of Aurora, 126 Colo. 267, 273, 248 P.2d 732,735 (1952) (en banc) ("Denver is a home-rule city and . . . Article XX of the Colorado Constitution gives Denver ample power ... to acquire by condemnation property already devoted to public use . . . .".). Beth Medrosh stressed that the power should be exercised only when "the overwhelming necessities of the public were such that, in order to serve their needs, . . . the taking . . . became necessary." "Id. at 274, 248 P.2d at 735 (quoting Denver Power \& Irrigation Co. v. Denver \& R.G. R.R., 30 Colo. 204, 212, 69 P. 568, 570 (1902)); see also City and County of Denver v. Board of Comm'rs, 113 Colo. 150, 158, 156 P.2d 101, 104 (1945) (en banc) ("[P]roperty devoted to a public use, under the stress of public necessity, may be condemned for another public use."); of. infra notes $72-79$ and accompanying text (discussing the "more necessary use" test).

${ }_{60} 1$ P. NICHOLS, supra note 8, § 2.2[2], at 2-81. Moreover, it has been held that the implication "must arise only from the language used" in the grant of power. Village of Blue Ash v. City of Cincinnati, 173 Ohio St. 345, 352, 182 N.E.2d 557, 562 (1962). 
adopted by the North Carolina Supreme Court when it was confronted with a city's plan to construct a dam for a hydroelectric plant that would submerge approximately twenty-five acres of a county home for indigents and inundate county roads at fifteen places. ${ }^{61}$ Affirming a trial court denial of the city's power to condemn the land, the court disposed of the argument that the city had power to condemn by necessary implication: "If an implication is to be relied upon, it must appear from . . . the application [of the enactment] to the particular subject matter of it, so that . . . some especial object sought to be attained by the exercise of the power granted could not be reached in any other ... manner." ",62

The latter, more flexible, stance was espoused by the Ohio Court of Appeals when it allowed a board of county commissioners to condemn for airport expansion that portion of a village's property not required for municipal buildings. ${ }^{63}$ Ordinarily, the court conceded, the power to take by necessary implication flows from statutory language; however, "resort may be had to the legislative intent as evidenced by a consideration of the statute with relation to its subject matter," and the power to take may be "inferred from a comparison of the conflicting powers conferred by the statute as well as the nature of the public works respectively to be undertaken."64

This second, more flexible stance shades into a third, more contro471 (1940).

${ }^{61}$ See Yadkin County v. City of High Point, 217 N.C. 462, 463-64, 8 S.E.2d 470,

${ }_{62}$ Id. at 467, 8 S.E.2d at 473 (quoting In re City of Buffalo, 68 N.Y. 167, 175 (1877)); see also Vermont Hydro-Elec., 95 Vt. at 152, 112 A. at 227 ("Such implication never arises except as a necessary condition to the beneficial enjoyment . . of the power expressly granted."); 2 J. LewIS, A TREatise on THE LAw of EMINENT DoMAIN IN THE UNITED STATES $\$ 440$, at 793 (3d ed. 1909) (" "[S]uch implication arises only from the language of the act . . . showing such taking to be necessary in order to beneficially enjoy and efficiently exercise the rights and privileges granted ...." "' (quoting Rutland-Canadian R.R. v. Central Vt. Ry., 72 Vt. 128, 133, 47 A. 399, 400 (1900) (footnote omitted))); 11 E. McQuillin, supra note 49, $\S 32.67$, at 403 (same).

${ }^{63}$ See Village of Richmond Heights v. Board of County Commr's, 112 Ohio App. 272, 284-85, 166 N.E.2d 143, 152 (1960), appeal dismissed per curiam, 171 Ohio St. 449, 172 N.E.2d 133 (1961).

64 Id. at 281,166 N.E.2d at 150 . Juxtaposing Richmond Heights with Village of Blue Ash, one scholar has remarked upon the Ohio court's "resilience in avoiding its own general rule." W. ValeNTE, Local GoverNMENT LAW 293 (1975); $c f$. Louisiana Power \& Light Co. v. City of Houma, 229 So. 2d 202, 207 (La. Ct. App.) ("IT]he implied necessity rule applies in those instances where the language of the statute, together with the legislative creation of the expropriating agency and the nature of the improvements authorized, require authority to expropriate property in public use."), cert. denied, 254 La. 1165, 229 So. 2d 350 (1969); 1 P. Nichols, supra note 8, $\S 2.2[1]$, at 2-78 ("[R]esort may be had to the determination of the legislative intent as evinced by a consideration of the statute with relation to the matter with which it is concerned."). 
versial approach to "necessary implication." This third approach compares the relative value and importance of the competing uses to determine which use will more substantially benefit the public. In Township of Weehawken $v$. Erie Railroad, ${ }^{6 s}$ the New Jersey Supreme Court modified the extent of township condemnation of railroad property for municipal parking and recreational facilities. The court reasoned that despite the benefit to the public from a parking lot, "it tends to lose proportion where the project would exclude a railroad operation for which the property is so highly adaptable."66 The court noted that some opinions had held that necessary implication "may only arise from facts which demonstrate that an exercise of the power is necessary to realize enjoyment of the privilege bestowed," while others had been cast "in terms of reasonable necessity and comparative value of the conflicting interests." ${ }^{\prime \prime 7}$ The court found persuasive support for the latter approach in a treatise on eminent domain, which it quoted at some length:

"As to the degree of necessity which must exist . . . the better opinion is that it must be a reasonable one. Whether any general rule can be laid down as to what will constitute a reasonable necessity, may be doubted. But we should say that there was a reasonable necessity for the taking where the public interests would be better subserved thereby, or where the advantages to the condemnor will largely exceed the disadvantages to the condemnee."

The court followed the lead of a New Jersey Superior Court decision that had allowed a sewer authority to condemn vacant land owned by a municipality. ${ }^{69}$ The earlier opinion also cited the treatise, stressed the sewer authority's "health function of concern to the State and . . . mu-

es 20 N.J. 572, 120 A.2d 593 (1956).

${ }^{68}$ Id. at 585,120 A.2d at 599 .

${ }^{67}$ Id. at 580,120 A.2d at 597.

es Id. (quoting $2 \mathrm{~J}$. LewIS, supra note $62, \S 440$, at 796). Actually, the quotation is misleading. The court omits two immediately preceding sentences in $A$ Treatise on the Law of Eminent Domain in the United States that cast the quoted material in an entirely different light: "Two conditions must concur in order to authorize such taking. There must be some necessity therefor on the part of the condemnor and the taking must not destroy or seriously impede the use to which the property is already devoted." 2 J. LEWIS, supra note $62, \S 440$, at 795-96 (emphasis added).

69 See Bergen County Sewer Auth. v. Borough of Little Ferry, 7 N.J. Super. 213, 72 A.2d 886 (App. Div.), appeal dismissed, 5 N.J. 548, 76 A.2d 680 (1950); see also State Highway Comm'n v. City of Elizabeth, 102 N.J. Eq. 221, 224, 140 A. 335, 338 (Ch.) (allowing the condemnation of municipal property by the state highway commission based, in part, on the abbreviated quote of 2 J. LEwIS, supra note $62, \S 440$, at 796, discussed supra note 68), affd per curiam, 103 N.J. Eq. 376, 143 A. 916 (1928). 
nicipalities," and hinted that "power to condemn municipally owned land used for lesser public needs or purposes might well be implied within the legislative grant."70 This hint was not dispositive, however, because the land in dispute was not being used. ${ }^{71}$

\section{The More Necessary Use Test}

The "more necessary use" test has assumed a variety of forms in different jurisdictions. Some courts conceive of the more necessary use test as an exception to the prior public use doctrine, applicable "when the proposed use is of superior rank in respect of public necessity."72 For example, when a city exercised its power of condemnation to "deal affirmatively with the crucial problem of urban decay" and sought to take land that was not indispensable to the operation of a public utility, a New York Supreme Court approved the taking as "a situation where the prior 'public use' must yield to the imperative of the greater public need."73

The Texas embodiment of the exception is narrowly drawn, demanding both that the "necessity be so great as to make the new enterprise of paramount importance to the public" and that it "cannot be

${ }^{20}$ Bergen County, 7 N.J. Super. at 219-20, 72 A.2d at 889; see also Easthampton v. County Comm'rs, 154 Mass. 424, 425, 28 N.E. 298, 298 (1891) ("We must consider the relative importance and the necessities of the two uses generally, the extent of the harm to be done, accept any light that history may throw, and make up our minds under all the circumstances . . .."); Note, Eminent Domain: Intergovernmental Conflicts, 29 IND. L.J. 206, 209 (1954) [hereinafter Note, Intergovernmental Conflicts] ("[T]he determination of necessary implication is really a determination of the best use for the particular land.").

71 It should be noted that courts have sometimes gratuitously discovered "necessary implication." See, e.g., Housing Auth. v. State Dep't of Transp., 385 So. 2d 690, 691 (Fla. Dist. Ct. App. 1980) ("Where one condemning authority possesses superior condemnation powers the required legislative intent . . . is necessarily implied."); City of Shakopee v. Clark, 295 N.W.2d 495, 498-99 (Minn. 1980) (noting that an implied right to condemn may be found when a condemnee has not put its land to public use or when proposed and pre-existing uses are not "substantially" inconsistent with those of the condemnee).

${ }^{72}$ Georgia S. \& Fla. Ry. v. State Rd. Dep't, 176 So. 2d 111, 112 (Fla. Dist. Ct. App. 1965) (dictum); see D. MANDELKER, supra note 49, at 161; 1 P. Nichols, supra note $8, \S 2.2[3]$, at 2-82; Phay, supra note 49 , at 354 .

${ }^{73}$ City of Rochester v. Rochester Gas \& Elec. Corp., 54 Misc. 2d 855, 859, 283 N.Y.S.2d 631, 635 (Sup. Ct. 1967); see also Oklahoma City v. Local Fed. Sav. \& Loan Ass'n, 192 Okla. 188, 196, 134 P.2d 565, 575 (1943) ("There are exceptions to [the] rule, but the exceptions apply only in those instances where the second taking is necessary to the public welfare."); $c f$. City of Buffalo v. Iroquois Gas Corp., 70 Misc. 2d 25, 27, 332 N.Y.S.2d 925,928 (Sup. Ct. 1972) (public utility successfully resisted a taking by the city on ground that "the priority of its present use outranks that contemplated in the urban redevelopment plans" because of the "emergency nature of services provided"). 
practically accomplished in any other way."74 This standard has been held to empower a school district to condemn park land for the paramount public use of a school site, ${ }^{75}$ but did not support a public utility's efforts to condemn, on the basis of its ability to provide better service, municipally owned electric facilities situated outside city limits. $^{78}$

Finally, some cases have been decided by the application of "more necessary use" provisions incorporated in state statutes. ${ }^{77}$ Looking to previous adjudication under such a statute, the Supreme Court of Montana found a practice of weighing the benefits to be derived from the condemnation against the impairments to the existing use of the land. ${ }^{78}$ The court noted the "broad range of considerations in determining whether a proposed public use is more necessary than the present use."'79

74 Gulf State Pipe Line Co. v. Orange County Water Control \& Improvement Dist., 526 S.W.2d 724, 726 (Tex. Civ. App. 1975); see also Fort Worth \& D. Ry. v. City of Houston, 672 S.W.2d 299, 300 (Tex. Ct. App. 1984) (holding that a condemnation that would practically destroy a property's existing use would be prohibited unless it was proven that the new enterprise was "of paramount public importance" and "its purpose [could not] be otherwise accomplished"); $c f$. State v. T.O.L., Inc., 206 So. 2d 69, 73 (Fla. Dist. Ct. App. 1968) ("A particular public easement may be imposed upon land already subject to a different public easement even in the absence of express legislative authority where the subsequent use is for a public purpose of . . . paramount importance which cannot be accomplished in any other practical way ....").

${ }^{75}$ See Austin Indep. School Dist. v. Sierra Club, 495 S.W.2d 878, 880, 882 (Tex. 1973); cf. El Paso County v. City of El Paso, 357 S.W.2d 783, 785 (Tex. Civ. App. 1962) (dictum) ("[O]ne political subdivision . . . can condemn the land of another, the decision resting, of course, on the paramount use and the best interests of the public."); Harris County Drainage Dist. v. City of Houston, 35 S.W.2d 118, 122 (Tex. Comm'n App. 1931) (stating hypothetically that the city may exercise its power of eminent domain in order to make improvements for the benefit of its citizens "if the necessity be so great as to make the new enterprise of paramount importance to the public and can be practically accomplished in no other way"); Dau, supra note 3, at 1522-23 (discussing "paramount use").

${ }^{76}$ See Louisiana Power \& Light Co. v. City of Houma, 229 So. 2d 202, 211 (La. Ct. App.) (applying a standard identical to that applied in Texas: the use "may be of such paramount public importance as to justify taking of property devoted to a lesser . . . use, where the superior use cannot be accomplished in any other practicable manner."), cert. denied, 254 La. 1165, 229 So. 2d 350 (1969).

${ }_{77}$ See, e.g., State v. City of Big Timber, 165 Mont. 328, 334, 528 P.2d 688, 691 (1974) (statute requires that public property be condemned only if proposed use is more necessary than existing use); Board of Educ. v. Park Dist., 70 N.W.2d 899, 906 (N.D. 1955) (same). For a critique detailing the shortcomings of such statutory provisions, see Matteoni, supra note 22, at 569-70 (acknowledging that the legislature "cannot possibly define an order of public use priorities that would cover every situation," but nevertheless faulting the uncertainties regarding interpretation of the phrase "more necessary public use").

${ }^{78}$ See City of Missoula v. Mountain Water Co., 743 P.2d 590, 595 (Mont. 1987).

${ }^{29}$ Id. 
The prior public use model posited in Part II of this Comment opts for the Texas embodiment of the "more necessary use" test as the best way to reconcile "occupation" and "social utility" considerations in public use conflicts. A prior public use doctrine without such a test risks rigidly overprotecting possession at the expense of social utility, while, on the other hand, a broader version of the test risks an undue subordination of possession to the "greater good" of social utility. ${ }^{\mathbf{8 0}}$

\section{F. The "Character" of the Condemnor and Condemnee}

The foregoing "more necessary use" inquiry introduces the last interpretive concern generated by the prior public use doctrine: the question of the significance to be attributed to the nature or status-the "character," as the treatises put $\mathrm{it}^{\mathbf{8 1}}$-of the condemnor and condemnee. $^{82}$ Some courts rationalize the condemnation by a municipality of a public service corporation's facilities, for the same use, on the ground that "the use by the municipal corporation is a more necessary one than is the use by a private organization." 83 Unfortunately, the opinions purporting to rest on a "more necessary use" rationale sometimes do not so much proffer reasoned analysis of how the same use is transformed into a more necessary use under different hands as they make the bare assertion "municipal, ergo more necessary."

In Duck River Electric Membership Corp. v. City of Manchester, ${ }^{84}$ the Tennessee Supreme Court articulated the assumptions underlying this rationale:

[W] hile we cast no aspersions upon these corporations . . . the fact remains that they are manifestly low-grade, volunteer public service type corporations, inferior in all respects, to municipalities which exist for the purpose of general government. Cities enjoy perpetual succession . . . They enjoy a higher degree of permanency and a greater degree of

so See infra notes 158-69 and accompanying text.

S1 See 11 E. McQuILIIN, supra note 49; § 32.72, at 414; 1 P. Nichols, supra note $8, \S 2.2$, at $2-55$.

${ }_{82}$ This topic was discussed supra notes $43-48$ and accompanying text.

${ }^{83}$ Unity Light \& Power Co. v. City of Burley, 92 Idaho 499, 504, 445 P.2d 720, 725 (1968): see also People ex rel. Public Util. Comm'n v. City of Fresno, 254 Cal. App. 2d 76, 85, 62 Cal. Rptr. 79, 85 (1967) ("[T]he Legislature has expressly stated that when public utility property already appropriated to public use is condemned by a city, the contemplated city use is "the more necessary public use' as a matter of law."); cf. Santa Cruz Irrigation Dist. v. City of Tucson, 108 Ariz. 152, 153, 494 P.2d 24, 25 (1972) ("[W]here the public use is incidental to the basic purpose of the organization of an irrigation district, the services are a more necessary public use when offered by a municipality.").

B4 529 S.W.2d 202 (Tenn. 1975). 
stability.

... [T] here can be no legitimate contention but that the city distribution of electric current will be a higher public use.

Manchester may condemn. It will hold the property so acquired for the general public benefit, with a higher and larger scope of use and under a more stable and responsive system. ${ }^{85}$

As a treatise on eminent domain has stated, "If . . . the purpose of such acquisition is to transfer the ownership and operation . . . from a public service corporation . . . to a municipality . . . it has been held that the greater public use and increased public benefit which result from governmental operation justify such acquisition."86

Nevertheless, discordant voices can also be heard on this issue. In City of Missoula $v$. Mountain Water Co. ${ }^{87}$ the city sought to acquire a privately owned water distribution business through condemnation. Because the water was already appropriated to a public use, the district court had to determine, under the relevant statute, whether the city's use would constitute a "more necessary public use"; it held that the city had failed to prove that the taking of the system was necessary. ${ }^{88}$ The Supreme Court of Montana remanded, directing the district court to weigh the benefits of public versus private ownership of the water sys-

${ }^{80}$ Id. at 206-07; see also City of Blue Springs, 684 S.W.2d at 51 ("A municipal corporation is a public and governmental agency. It [holds] property for the general benefit, with a larger scope of use." (quoting Illinois Cities Water Co. v. Gity of Mount Vernon, 11 Ill. 2d 547, 554, 144 N.E.2d 729, 733 (1957))).

${ }_{88} 1$ P. Nichols, supra note 8, § 2.2[9], at 2-102; see also City of Palm Bay v. General Dev. Utils., 201 So. 2d 912, 915-16 (Fla. Dist. Ct. App.) (citing 1 P. NICHoLS, supra note $8, \S 2.39[9]$, and adding that "[s]urely as a policy consideration the petitioner's citizenry, operating through their selected representatives have a right to expect their governmental unit to provide them with services within its proper sphere"), cert. denied, 207 So. 2d 452 (Fla. 1967); City of Shakopee v. Minnesota Valley Elec. Coop., 303 N.W.2d 58, 60 (Minn. 1981) (citing 1 P. NICHOLs, supra note 8, § 2.2[9], at 2-102); 11 E. MCQUILLIN, supra note $49, \S 32.69$, at 407-08 (municipality may take the property of a private corporation if the public interest is better served); Dau, supra note 3 , at 1520-21 (stating that a greater public use justifies a municipality taking property devoted to a public use and applying it to the same use, although a private corporation cannot do the same); Note, Municipal Acquisition of Public Utilities, 34 Colum. L. REv. 534, 534 (1934) ("II]n the hands of a governmental agency the plant will be run primarily, and not incidentally, for the convenience of the community-the 'same' use thus becomes a 'more necessary' one.").

87743 P.2d 590 (Mont. 1987).

88 See id. at 595. 
tem. ${ }^{89}$ These instructions elicited a strong dissent, which argued:

Where the majority stray into error is their implicit assumption that the City of Missoula, as a governmental entity, stands in a better position as a condemnor for purposes of public use than Mountain Water Company, a private corporation. No such distinction is made in our statutes. . . . This case is not the stage on which to debate public ownership versus private ownership of property. Public ownership of Missoula's water supply system cannot be a factor of necessity, because all condemnors, whether public or private, stand on equal footing before the law in condemnation proceedings. ${ }^{90}$

The Supreme Court of Oklahoma held, in City of Pryor Creek $v$. Public Service Co., ${ }^{\text {o1 }}$ that the general power of eminent domain did not authorize a municipality to condemn a public service corporation's facilities and use them for the same purpose, absent specific statutory authorization. ${ }^{92}$ The court reasoned that the legislature had demonstrated its awareness of this insufficiency by enacting specific statutes, none of which applied in the instant case, "to deal with these problems." 93 Apparently unpersuaded by the higher public use rationale, the court argued that " $\mathrm{t}] \mathrm{c}$ hold otherwise would amount simply to the taking of property from one and destroying his right to operate although expressly authorized to do so, and giving it to another without any benefit to the public."

Similarly, in Town of Culpeper v. Virginia Electric and Power Co., ${ }^{95}$ the Virginia Supreme Court found no procedure in Virginia "under which annexing towns and cities can acquire by eminent domain the facilities of a franchised utility." The court stressed that a certificate of public convenience is a property right, entitled to protection by the courts. ${ }^{97}$

An analogous split in authority appears when a political subdivision seeks to condemn the land of a public use corporation and put it to a different use. One view is that "[a] municipal corporation having the

${ }^{89}$ See id. at 596.

${ }^{80}$ Id. at 597 (Sheehy, J., dissenting).

91536 P.2d 343 (Okla. 1975).

92 See id. at 347.

${ }^{83}$ Id. at 346.

94 Id.

95 215 Va. 189, 207 S.E.2d 864 (1974).

${ }^{98} I d$. at 193,207 S.E.2d at 867.

97 See id. at 193-94, 207 S.E.2d at 867-68. 
right of eminent domain stands no differently before the courts than a private corporation clothed with the same right." ${ }^{\text {s8 }}$ On the other hand, as the North Carolina Supreme Court has explained, some courts have discriminated between municipal corporations and private corporations when applying the prior public use doctrine. ${ }^{99}$ These courts would extend the full protection of the doctrine when a political subdivision is the resisting land owner by "strictly observ[ing]" its provisions, but would "somewhat relax" the rule's rigor when a public service corporation is the condemnee because "in the [political subdivision] the public interest alone is supposed to prevail while in the [private corporation] the idea of private enterprise also plays a part." ${ }^{\prime 100}$

The character of the condemnor attains the greatest significance when the court finds the condemnor to be the sovereign itself. ${ }^{101}$ When the condemnor is the sovereign, or is acting on behalf of the sovereign, courts generally defer to the taking and deem the prior public use doctrine inapposite. ${ }^{102}$ However, just when the condemnor is the sovereign

${ }^{98}$ Vermont Hydro-Elect., 95 Vt. at 153, 112 A. at 227; see also Florida E. Coast Ry. v. City of Miami, 321 So. 2d 545, 548 (Fla. 1975) (refusing to distinguish a cause involving two public bodies from a cause involving a public body and a franchised public use company); Cemetery Co. v. Warren School Township, 236 Ind. 171, 186, 139 N.E.2d 538, 545 (1957) ("The public use of land by a private utility for water, light, and communication might appear to many persons to be of as great, if not greater, public concern and interest than that of some other governmental uses which might be asked in the name of the sovereign state."); Kansas City v. Ashley, 406 S.W.2d 584, 590 (Mo. 1966) (holding that the city lacked the power to condemn railroad property already devoted to public use).

${ }^{89}$ See Yadkin County, 217 N.C. at 466, 8 S.E.2d at 473; see also Cemetery Co., 236 Ind. at $185-86,139$ N.E.2d at 545 ("Such jurisdictions hold that a state or its agency (as distinguished from a private corporation or privately owned utility exercising the power of eminent domain) under a general grant of power may take property already devoted to a public use by a private corporation such as a railroad, cemetery company, or utility. This is done on the theory that the governmental body is acting for the sovereign ....").

100 Yadkin County, 217 N.C. at 466, 85 S.E.2d at 473.

101 For pronouncements of the paramount significance of the character of the condemnor, see Hiland v. Ives, 154 Conn. 683, 688, 228 A.2d 502, 504 (1967); Louisiana Power \& Light Co. v. City of Houma, 229 So. 2d 202, 206 (La. Ct. App.), cert. denied, 254 La. 1165, 229 So. 2 d 350 (1969); 1 P. Nichols, supra note 8, § 2.2, at 255.

102 See, e.g., Hiland, 154 Conn. at 688, 228 A.2d at 504 ("But the rule does not apply where the sovereign itself is the condemnor and is taking the property on its own behalf and for its own sovereign purposes."); City of Wilmington v. Lord, 340 A.2d $182,183-84$ (Del. Super. Ct. 1975) ("[A]s a home rule city, Wilmington is to be considered the sovereign for the purposes of municipal functions," and it can take public property by eminent domain.); Housing Auth. v. State Dep't of Transp., 385 So. 2d 690, 691-92 (Fla. Dist. Ct. App. 1980) (The Department of Transportation "is the sovereign when acting in the area of State road building," and therefore the prior public use doctrine does not apply.); Louisiana Power E' Light Co., 229 So. 2d at 206 (" 'If the sovereign on its own behalf seeks to acquire such property by eminent domain, the fact that the land sought to be taken is public property generally is immate- 
is unclear. Some cases establish a dichotomy between delegation and agency: if the condemnor is a municipal or private corporation to which the state has delegated a portion of its sovereign power of eminent domain, then the prior public use doctrine is operative; if, on the other hand, the condemnor is the designated agent of the state, typically a state highway commission or department of transportation, then the state is acting through its agent and the power is, in effect, exercised by the state itself, rendering the rule inoperative. ${ }^{103}$ Other cases, however, do not divorce the concepts of delegation and agency and hold that the prior public use doctrine applies when the power of eminent domain has been delegated to an agent. ${ }^{104}$

The prior public use model advocated in Part II of this Comment does not attach significance to the character of the condemnor and condemnee when a political subdivision seeks to acquire property of a public service corporation. Such a jurisdictional exercise undermines the "occupation" element in property without enhancing the "social utility" element. ${ }^{105}$

rial.' " (quoting State v. Ouachita Parish School Bd., 242 La. 682, 689, 138 So. 2d 109, 112 (1961))); Dau, supra note 3, at 1520 ("Whenever the interests of the public require, the state may condemn for a different public use property previously devoted to a public use.").

103 See Hiland, 154 Conn. at 691-92, 228 A.2d at 506; Southern Ry. v. State Highway Dep't, 219 Ga. 435, 439, 134 S.E.2d 12, 15-16 (1963); cf. Note, Intergovernmental Conflicts, supra note 70, at 209 (noting that courts regard state agencies and home rule cities as acting for the sovereign).

${ }^{104}$ See, e.g., City of Wilmington, $340 \mathrm{~A} .2 \mathrm{~d}$ at 184 (stating as a general rule that "the sovereign may take public property . . . but that an agency of the sovereign to whom eminent domain has been delegated may only take public property if the legislature has manifested its consent to the taking ... in express terms or by necessary implication"); Louisiana Power E' Light Co., 229 So. 2d at 206 ("[A] subdivision or agency of the state does not possess authority to expropriate property in public use unless such authority is expressly conferred . . . ."); cf. Southern Ry., $219 \mathrm{Ga}$. at $442-$ 44, 134 S.E.2d at 17-18 (Duckworth, C.J., partially concurring in judgment, partially dissenting in judgment, and dissenting in opinion) (" $[\mathrm{I}] \mathrm{t}$ is begging the question . . . to say that the Highway Department is the State. . . . The State legislature invested the Highway Department with the power to take private property for a public use by eminent domain .... in the same degree and only to the extent it did this railroad. . . . A reference to the legislative Acts which confer upon the Department the right to take property . . . shows that they simply delegated that power to the department . . . ."); Note, Intergovernmental Conflicts, supra note 70, at 210 ("There is no sound reason for holding state agencies and home rule cities to a different standard from political subdivisions and nongovernmental bodies.").

The ambiguities are compounded by language indicating that state government is administered through the agency of municipalities. See, e.g., Medical Center Comm'n v. Powell, 124 Ill. App. 2d 123, 131, 260 N.E.2d 261, 264 (1970) (" The statute does not authorize the taking of the property of the state, or of the subordinate municipalities through whose agency the state government is administered, by the exercise of the right of eminent domain." " (quoting City of Edwardsville v. County of Madison, 251 Ill. 265, 266-67, 96 N.E. 238, 238 (1911))).

${ }^{105}$ See infra notes $177-83$ and accompanying text. 


\section{A Model Prior Public Use Jurisprudence}

The preceding analysis of variations in judicial interpretation and application of the prior public use doctrine serves here as a springboard for evaluating the appropriate judicial role in prior public use adjudication. It is safe enough to assert that the question whether property is being "used" is a question of fact to be determined by the courts; ${ }^{106}$ that the question whether a use is a public use is an issue to be resolved by the courts; ${ }^{107}$ that the question whether uses are compatible is a factual question to be determined by the courts; ${ }^{103}$ that the degree of necessity required to give rise to an implication of legislative authorization of taking is a judicial question; ${ }^{\mathbf{1 0 9}}$ and that under "more necessary use" statutes the question of greater necessity is properly tried to the court. ${ }^{110}$ But should the issue of public use be resolved with reference to a bright line rule or on an ad hoc basis? Should a necessary implication of legislative authorization require absolute or merely reasonable necessity? Should courts weigh the relative importance of competing uses-either with the blessing of statutes or without?

\section{A. The "Occupation" and "Social Utility" Theories of Property}

In order to answer the questions posed above, this Comment first formulates its own policy underpinnings for the prior public use doctrine, importing by analogy to private ownership the "occupation" and "social utility" theories of property. As Part I noted, the doctrine's talismanic stature has reduced analysis of the reasons for the rule to a reflex recitation that contributes nothing to a resolution of problems in prior public use adjudication. ${ }^{111}$

Private ownership theories may be readily transplanted to a public use context and applied to municipal and private corporations alike. As Gerald Frug has demonstrated, in pre-nineteenth century England and America, public and private corporations, cities and businesses, were not distinguished; all these corporations had the same legal rights. ${ }^{112}$

${ }^{108}$ See East Bay Mun. Util. Dist. v. City of Lodi, 120 Gal. App. 740, 753, 8 P.2d 532, 537 (1932); Vermont Hydro-Elec. Corp. v. Dunn, 95 Vt. 144, 150, 112 A. 223, 226 (1921).

107 See City of New Haven v. Town of E. Haven, 35 Conn. Supp. 157, 165, 402 A.2d 345, 350 (1977), aff d, 177 Conn. 749, 419 A.2d 349 (1979); Tuomey Hosp. v. City of Sumter, 243 S.C. 544, 552, 134 S.E.2d 744, 748 (1964).

${ }^{108}$ See Minnesota Power \& Light Co. v. State, 177 Minn. 343, 350, 225 N.W. 164, 167 (1929); Ball, supra note 8, at 35.

108 See 1 P. Nichols, supra note $8, \S 2.2[3]$, at 2-82.

110 See Board of Educ. v. Park Dist., 70 N.W.2d 899, 905 (N.D. 1955).

111 See supra notes 18-25 and accompanying text.

112 See Frug, The City as a Legal Concept, 93 HARv. L. Rev. 1057, 1082 (1980). 
The adoption in nineteenth century America of the public/private distinction assigned private corporations the identity of "persons"113_relegating them to the "Lockean sphere of rights"114_but assigned cities the identity of state subdivisions ${ }^{116}$ - relegating them to the "Hobbesian sphere of command"116 and domination by state legislative power. ${ }^{117}$ The twentieth century erosion of the public/private dichotomy, however, has undercut the conventional bases for distinguishing public from private corporations. ${ }^{118}$ Frug reveals "the virtual impossibility of a meaningful, nonpolitical distinction between functions 'naturally' performed by public or by private corporations, between 'public goods' and 'private goods.' "119

The best rationale for the prior public use doctrine, then, is its potential for accommodating both the "occupation" and "social utility" aspects of property. On the one hand, "occupation" values direct that possession should be protected. ${ }^{120}$ On the other hand, "social utility" values direct that property should be used in the manner that best promotes the "maximum fulfillment of human needs." two views of property are not mutually exclusive. Richard Posner, for example, has argued that the "legal protection of property rights cre-
$113 \mathrm{Id}$. at 1121.
114 Id. at 1095.
115 See id. at 1121.
116 Id. at 1095.
117 See id. at 1120-21.
118 See id. at 1139-40.

$119 \mathrm{Id}$. at 1138. Frug depicts the courts' failure to draw a workable "public/private [i.e., governmental/proprietary] distinction within municipal corporation law" and then pointedly observes the irony of "[t]his ability [of the courts] to denounce the public/private distinction within municipal corporation law while insisting upon it when comparing cities to private corporations." Id. at $1140 \mathrm{n} .359$; see also D. MANDELKER, supra note 49, at 438 (describing the "universally acknowledged" confusion in "judicial attempts to define what is governmental and what is proprietary"); Reynolds, The Judicial Role in Intergovernmental Land Use Disputes: The Case Against Balancing, 71 MiNN. L. REv. 611, 623 (1987) (stating that many courts suggest the distinction between governmental and proprietary functions "is illusory"); $c f$. Wells \& Hellerstein, The Governmental-Proprietary Distinction in Constitutional Law, 66 VA. L. REv. 1073,1136 (1980) ("The terms 'governmental' and 'proprietary' are best viewed as labels expressing the conclusion that particular government activity should be accorded a particular legal status and not as standards to be used in reaching such a conclusion. . . . Courts could pursue each of the purposes [the governmental/proprietary distinction] serves by focusing directly on the underlying values themselves . . . .").

${ }^{120}$ See R. Gunningham, supra note 3, at 2; Cohen, Property and Sovereignty, 13 CoRNell L.Q. 8, 15 (1927).

121 R. Cunningham, supra note 3, at 2 ; see also R. Posner, Economic ANalySIS of LAw 18 (1972) ("These observations suggest an economic principle for deciding, in cases of conflicting land (or other property) uses, which party shall have the right to exclude the other. The right should be assigned to the party whose use is the more valuable . . .."). 
ates incentives to use resources efficiently,"122 while Bentham's "idea of property" as "an established expectation"123 posits that only through protection of such an expectation "can we hope for a minimally acceptable level of productivity."124 Nevertheless, there is a tension between the "occupation" and "social utility" notions of property. The former justifies legal protection of a possessor's claim by virtue of the simple fact of possession, regardless of whether the property is used to promote the greater good; the latter validates legal protection of property based upon its successful promotion of human needs and aspirations. ${ }^{125}$ The tension is between the "dominion" and "social" views of property, the former emphasizing discreteness, even atomism, the latter emphasizing the social whole. ${ }^{128}$

\section{B. The Tension in the Rule and a Principle for its Resolution}

The occupation-social utility tension animates the prior public use doctrine. Any implementation of the doctrine that forecloses evaluation of the "more necessary use" risks inflexibly overprotecting possession-the "abstract rights of ownership"127_at the expense of social value. In this scenario, courts labor under the constraint of excessive deference to the pre-existing use, sacrificing the flexibility necessary to realize "the imperative of the greater public need"128 or the "stress of public necessity."129 Yet a premise insistently asserted by courts and commentators-that the formulation of public policy is the province of the legislature, not the courts-disposes of the question whether courts should weigh the relative importance of competing uses absent statutory directives, as it is for the legislature to decide which uses redound to the greater public benefit. ${ }^{130}$

The nexus of an "occupation" property orientation with a restrained conception of the judicial function culminates in judicial pro-

122 R. Posner, Economic Analysis of Law 30 (3d ed. 1986).

123 J. Bentham, Theory of Legislation 112 (G. Ogden ed. 1931).

124 Michelman, Property, Utility, and Fairness: Comments on the Ethical Foundations of "Just Compensation" Law, 80 HaRv. L. Rev. 1165, 1212 (1967).

${ }^{125}$ See R. CunninghaM, supra note 3, at 2.

120 See Oakes, "Property Rights" in Constitutional Analysis Today, 56 WAsH. L. REV. 583, 587 (1981).

${ }_{127}$ Note, The Constitutionality of Rent Control Restrictions on Property Owners' Dominion Interests, 100 HARV. L. REV. 1067, 1085 (1987).

${ }_{128}$ City of Rochester v. Rochester Gas \& Elec. Corp., 54 Misc. 2d 855, 859, 283 N.Y.S.2d 631, 635 (Sup. Ct. 1967).

${ }_{129}$ City \& County of Denver v. Board of Comm'rs, 113 Colo. 150, 158, 156 P.2d 101, 104 (1945). (1921).

1so See Vermont Hydro-Elect. Corp. v. Dunn, 95 Vt. 144, 153, 112 A. 223, 227 
nouncements such as "[t]he doctrine of prior public use does not clothe the court with power to weigh the communal benefit of the proposed use against the present use of property sought to be condemned"131 and "the determination of the relative values and importance of different public uses . . . is purely a legislative matter-one of policy to be determined in the legislative halls and not in the court room."132 The commentators are in substantial agreement, ${ }^{133}$ one arguing that when courts consider the total impact of an acquisition upon the region, they act as land planning bodies in a legislative function that transcends their institutional competence. ${ }^{134}$

Taken to an extreme, however, this argument culminates in a disjuncture between the courts and social exigency, a disjuncture revealed, for example, by such rigidly categorical pronouncements as " $[t]$ his case must be controlled by legal principles and not by considering the practical effect . . . ."195 Such arid dogmatism seems especially incongruous in a land use context, when social utility, and perhaps even the solution of a crisis, is at stake. Moreover, to maintain that when the legislature enacts a statute conferring the power of eminent domain, it hands down its formulation of the best means to effectuate the greater public good, is to ignore reality; because "at the time a general grant is enacted, the controversy has not arisen," and the legislative process cannot respond adequately to subsequent conflicts. ${ }^{136}$ The legislature cannot possibly anticipate every clash between public uses, and a wooden adherence to the prior public use doctrine means that every time a conflict arises, the legislature must enact special legislation. ${ }^{\mathbf{1 3 z}}$ Furthermore, it is disingen-

191 Board of Educ. v. Pace College, 27 A.D.2d 87, 90, 276 N.Y.S.2d 162, 165 (1966), motion denied, 19 N.Y.2d 672, 225 N.E.2d 554, 278 N.Y.S.2d 862 (1967).

${ }^{132}$ Cemetery Co. v. Warren School Township, 236 Ind. 171, 187, 139 N.E.2d 538, 545 (1957); see also Board of Supervisors v. Board of County Supervisors, 206 Va. 730, 734, 146 S.E.2d 234, 237 (1966) (agreeing with language to the effect that courts of equity should not weigh the importance of conflicting appropriations of property or make equitable adjustments of the rights of the parties).

133 See, e.g., 11 E. MCQuiluIN, supra note 49, $\S 32.67$, at 402 (stating that the "relative necessity and expediency of such uses are matters of legislative policy"); Ball, supra note 8, at 35 (noting the "essentially legislative character of the determination of necessity"); $i d$. at 45 ("The devotion of property to public needs is a legislative problem . . . ."); Dau, supra note 3, at 1526 ("It also seems more fitting to have the legislature determine which uses shall be more necessary ....").

${ }^{134}$ See Phay, supra note 49, at 370, 373-74.

135 Village of Blue Ash v. Gity of Cincinnati, 173 Ohio St. 345, 352, 182 N.E.2d 557,562 (1962).

${ }_{136}$ Note, Intergovernmental Conflicts, supra note 70 , at 210 . This argument seriously undercuts the judicial rationalization of the prior public use doctrine as a means of effectuating legislative intent. See supra notes 19-21 and accompanying text.

${ }_{137}$ See Township of Weehawken v. Erie R.R., 20 N.J. 572, 579, 120 A.2d 593, 596 (1956); see also Ball, supra note 8, at 33 (stating that the view that changes must depend on a special statute has been rejected). This problem has prompted legislatures 
uous to imply that courts do not embroil themselves in policy matters; ${ }^{138}$ the process of weighing conflicting interests is also not unheard of in the judiciary: "Only the courts are qualified to weigh the conflicting interests, thus, it is their duty to see that the best use for the particular land prevails."139

If the "occupation" theory-judicial restraint nexus lends itself to an absolute property rule that impedes the courts from considering societal interests, ${ }^{140}$ an unbridled "social utility" tilt conferring broad license to evaluate the "more necessary use" lends itself to virtual nullification of the possessory protections the prior public use doctrine affords. For example, in NL Industries, Inc. v. Eisenman Chemical Co., ${ }^{141}$ Eisenman, a competitor of NL in the barite mining industry, sought to occupy a portion of NL's mining property. ${ }^{142} \mathrm{NL}$ was holding barite in reserve, while Eisenman planned immediate extraction of the ore. ${ }^{143}$ Based on these facts, the district court had granted Eisenman exclusive and immediate occupancy, because "the holding of mineral reserves is a mining use, but the development and mining of mineral

to amend statutes to provide for the taking of public property. See, e.g., City of E. Peoria v. Group Five Dev. Co., 87 Ill. 2d 42, 45-46, 429 N.E.2d 492, 493-94 (1981) (discussing such a legislative amendment in Illinois).

${ }^{138}$ See Baker v. Sockwell, 80 Colo. 309, 311, 251 P. 543, 544 (1926) (en banc); Great N. Oil Co. v. St. Paul Fire \& Marine Ins. Co., 291 Minn. 97, 103, 189 N.W.2d 404, 408 (1971); Isherwood v. H.L. Jenkins Lumber Co., 87 Minn. 388, 390, 92 N.W. 230, 231 (1902); Tillinghast v. Merrill, 151 N.Y. 135, 136, 45 N.E. 375, 375 (1896); Sochemaro v. Rossetti, 6 Misc. 2d 23, 26, 161 N.Y.S.2d 454, 458 (Civ. Ct. 1957); S.S. Kresge Co. v. Port of Longview, 18 Wash. App. 805, 810, 573 P.2d 1336, 1340 (1977); Citizens State Bank v. Timm, Schmidt \& Co., 113 Wis. 2d 376, 386-88, 335 N.W.2d 361, 365-67 (1983).

139 Note, Intergovernmental Conflicts, supra note 70, at 210-11 (footnotes omitted). Regarding the general issue of the weighing of conflicting interests by courts, see Drummond v. Stahl, 127 Ariz. 122, 126, 618 P.2d 616, 620 (Ct. App. 1980), cert. denied, 450 U.S. 967 (1981); Calligan v. Superior Court, 230 Cal. Rptr. 388, 391-92 (1986); Peterson v. Town of Oxford, 189 Conn. 740, 746, 459 A.2d 100, 103 (1983); Thomas Patrick, Inc. v. KWK Inv. Co., 357 Mo. 100, 104, 206 S.W.2d 359, 360 (1947); State ex rel. Anheuser v. Nolan, 692 S.W.2d 325, 328 (Mo. Ct. App. 1985); State ex rel. Hoffman v. Campbell, 428 S.W.2d 904, 906 (Mo. Ct. App. 1968); Cynthia B. v. New Rochelle Hosp. Medical Center, 60 N.Y.2d 452, 461, 458 N.E.2d 363, 368, 470 N.Y.S.2d 122, 127 (1983); People v. Riley, 98 Misc. 2d 454, 458, 414 N.Y.S.2d 441, 443 (Sup. Ct. 1979); Glark v. Geraci, 29 Misc. 2d 791, 794, 208 N.Y.S.2d 564, 569 (Sup. Ct. 1960); Hyszko v. Barbour, 448 A.2d 723, 726 (R.I. 1982).

${ }_{140}$ Cf. Lazarus, Changing Conceptions of Property and Sovereignty in Natural Resources: Questioning the Public Trust Doctrine, 71 Iowa L. REv. 631, 663 n.211 (1986) ("With industrialization and urbanization, conflicts occurred increasingly between property owners and it became clear that applying absolute property rules could no longer resolve those conflicts. It was necessary to consider the interest of society .....").

${ }_{141} 98$ Nev. 253, 645 P.2d 976 (1982).

342 See id. at 255,645 P.2d at 978 .

34 See id. at 256, 645 P.2d at 979. 
rights or a mineral deposit is a more necessary public use."144 The Supreme Court of Nevada rejected the lower court's determination that "immediate extraction and production of mineral resources [constituted] . . . a more necessary public use than holding ore in reserve for future mining."145

In this scenario, when the test in effect displaces the doctrine and invites a weighing of the importance of the proposed use against that of the pre-existing use, courts are tempted to assume the role of social engineer, abdicating their responsibilities as guardians of ownership rights. It is precisely the judiciary's responsiveness to these rights, however, that furnishes the most powerful argument for judicial involvement in public use conflicts, in contrast to those commentators who advocate such drastic curtailment of judicial involvement as to obviate any need for a prior public use doctrine. Robert Phay proposes a state land planning agency to adjudicate conflicts in the intergovernmental context, with judicial review limited to procedural considerations. ${ }^{148}$ Vaughn Ball proposes the establishment of a clearly demarcated hierarchy of regulatory agencies that would have jurisdiction to approve or order condemnations on the "more necessary"147 use basis because "[it] is better to draw a few clear lines of authority than to expose each case to the toils of litigation."148

The reply to such proposals is that conflicts between public uses implicate concerns not only of social utility and efficiency, "matter[s] of engineering,"148 but also possessory rights. The courts, more than any narrowly specialized agency, are competent to be cognizant of, and responsive to, these rights. ${ }^{150}$ Such responsiveness is especially crucial in

\footnotetext{
14 Id. at $256-57,645$ P.2d at 979.

14 Id. at 257,645 P.2d at 979.

${ }^{146}$ See Phay, supra note 49 , at $375,379-80$.

147 Ball, supra note 8 , at 42 .
}

148 Id. at 45 . However, Ball acknowledges that this proposal is more practicable at the federal level and encounters thorny obstacles at the intrastate level, where "the outlines of the hierarchy necessary to the jurisdictional method are indefinite. . . . Counties, townships, municipalities, and special-purpose districts form a stratification many layers deep over the same land area. Their relative authorities are uncertain ...."Id. at 43; see also Note, Intergovernmental Conflicts, supra note 70, at 211 (noting that coordination of agencies empowered to acquire land would be more difficult at the state level).

140 Ball, supra note 8 , at 45 .

iso Cf. P. Carrington, D. Meador \& M. Rosenberg, Justice on Appeal 168 (1976) (stating that specialized courts with specialized judges may be 1) vulnerable to political manipulation; 2) conducive to an obliviousness to "the basic values at stake in their decisions"; and 3) considered less prestigious and therefore not attractive to more able judges); Commission on Revision of the Federal Court Appellate System, Structure and Internal Procedures: Recommendations for Change, 67 F.R.D. 195, 234-35 (1975) (discussing such inherent disadvantages of specialized courts as 1) judi- 
the condemnation context, because the power of eminent domain is "one of the attributes of sovereignty most susceptible of abuse and injustice." "151 And "absolute discretionary power" may be "a dangerous power in the hands of $\mathrm{a}[\mathrm{l}$. . . state agency."152

Therefore, courts should, even as they are mindful of the importance of social utility and development, be vigilant against "the whims of an operator of a slide rule or drawer of a blueprint"1ss and against the use of "the strong arm of government . . . to take property already dedicated to a proper public use."154 Regarding the preference for "clear lines of authority" to "the toils of litigation," the judicial "reluctan[ce] to approve governmental shortcuts when personal and property rights are involved"155 is a more prudent view. As the Illinois Appellate Court has stated, "With the court being the arbiter we have assurance that there will not be an abuse by public bodies in their exercise of the power of eminent domain."156 Furthermore, agency adjudication has been criticized as "often mistake ridden and hampered by a variety of institutional and bureaucratic constraints that undercut the quality of deliberation."157

Thus, the unbridled "social utility" tilt conferring broad license to evaluate the "more necessary use" lends itself to virtual nullification of the possessory protections afforded by the prior public use doctrine, while the "occupation" theory-judicial restraint nexus lends itself to an absolute property rule that impedes the courts from considering societal interests. The tension is inherent in the doctrine. The best rationale for the doctrine, however, is its potential for accommodating both the "occupation" and "social utility" aspects of property in order to resolve the tension. This potential is realized by the courts' ability, and duty, to be responsive to both aspects of property in interpreting and applying the

cial "tunnel vision," in which cases are viewed only in narrow perspective and the law becomes excessively esoteric; 2) the risk that specialized judges might impose their personal policy views; 3) the potential for undue compromises in the quality of appointments; 4) the potential for special interest groups to "capture" the court; and 5) the temptation to stint on the production of reasoned opinions to support decisions).

151 Recent Cases, Eminent Domain-Power of One Public Utility Corporation to Condemn Land of Similar Corporation, 80 U. PA. L. REv. 914, 914 (1932).

152 State Highway Comm'n v. City of Elizabeth, 102 N.J. Eq. 221, 229, 140 A. 335, 338 (Ch.), affd, 103 N.J. Eq. 376, 143 A. 916 (1928).

${ }_{153}$ Southern Ry. v. State Highway Dep't, 219 Ga. 435, 444, 134 S.E.2d 12, 18 (1963) (Duckworth, C.J., partially concurring in judgment, partially dissenting in judgment, and dissenting in opinion).

154 Southern Ry. v. City of Greensboro, 247 N.C. 321, 328-29, 101 S.E.2d 347,

355 (1957).

iss Id. at 330,101 S.E.2d at 355.

${ }^{106}$ City of E. Peoria v. Group Five Dev. Co., 90 Ill. App. 3d 729, 733, 413

N.E.2d 472, 476 (1980), affd, 87 Ill. 2d 42, 429 N.E.2d 492 (1981).

167 Resnik, Managerial Judges, 96 HARv. L. REv. 374, 440 (1982). 
prior public use doctrine. The principle is judicial protection of possession or occupation, tempered by judicial mindfulness of the desirability of utilizing property in the most socially valuable way. This principle generates specific rules for interpretation and application that are responsive to the tension.

\section{G. Resolving the Tension: The Paramount Importance Test}

The principle adduced above is achieved neither by an absolute property rule nor by an open invitation to an ad hoc weighing of the "more necessary use." Instead, this principle is most faithfully effectuated by the narrowly drawn formulation of the "paramount importance" test, requiring that the proposed use be of paramount necessity to the public and that it cannot be practically accomplished in any other way. ${ }^{168}$ This formulation enables courts to be responsive to both the "social utility" and "occupation" elements of prior public use adjudication. Requiring the condemnor to satisfy the heightened standard that the proposed use be of paramount importance to the public should demand a more compelling showing of exigency than the "more necessary" standard. The further requirement that the use cannot be practically accomplished in any other way imposes on the condemnor the burden of demonstrating that it has considered the feasibility of effecting its allegedly paramount use through less intrusive means. For example, in Central Power E Light Co. v. Willacy County, ${ }^{159}$ the county sought to take the power company's right of way in order to widen the adjacent highway. The extension would require removal of the company's electrical poles, wires, and other equipment. Reversing a judg-

188 This test, sometimes referred to as the "Texas rule," originated in Sabine \& E.T. Ry. v. Gulf \& I. Ry., 92 Tex. 162, 46 S.W. 784 (1898). In that case, a parcel of land acquired by one railroad for yard purposes and dedicated to public use was sought for condemnation by another railroad that wished to obtain a crossing in order to connect with a third line. The crossing would have destroyed the use of the land for yard purposes. The Texas Supreme Court held that
the law does not authorize the condemnation of property which has al- ready been dedicated to a public use, when such condemnation would practically destroy the use to which it has been devoted .... unless the necessity be so great as to make the new enterprise of paramount impor- tance to the public and cannot be practically accomplished in any other way.

Id. at $166,46 \mathrm{S.W}$. at 786 . The court emphasized the "paramount importance" requirement, holding that the new use must be "of so great importance to the public as to demand that another public use of less importance shall be set aside for its benefit ..."Id. at $168,46 \mathrm{~S} . \mathrm{W}$. at 787 . One commentator has noted that this requirement is apparently peculiar to Texas. See Dau, supra note 3, at 1522-23.

For a general discussion of the Texas rule, see $i d$. at 1522-26.

15814 S.W.2d 102 (Tex. Civ. App. 1929). 
ment of condemnation, the Texas Court of Civil Appeals acknowledged that the widening of a great public highway could easily be of such paramount importance to the public to justify the taking. ${ }^{180}$ The court stressed, however, that the additional requisite-that there was "no other practical way by which the object of the condemnation proceedings could be accomplished"- had not been demonstrated. ${ }^{\mathbf{1 6 1}}$

These requirements ensure adequate protection of the pre-existing use while enabling the courts to approve the taking if the condemnor has proven the requisite need. The stringency of the "paramount importance" test admits enough flexibility to respond to social exigency, yet allays the "occupation" misgivings about the broader "more necessary use" test, poignantly expressed by one judge in the context of a county-village conflict:

This doctrine I cannot agree with, for without legislative sanction, and by pure judicial decree, such doctrine would, more often than not, permit an expanding political subdivision, with great planning and financial resources, to plunder the small political subdivision, without such resources, but which wanted to do for its residents as it saw best . . . . ${ }^{162}$

It also addresses the prevailing judicial rationalization for the prior public use doctrine-that it averts circular or recriminatory condemnations ${ }^{163}$ _because "[o]nce the determination of superior use is made, it supplants the inferior leaving no ground for retaliation."164

Given the controversy over the legitimacy of judicial implementation of a "more necessary use" test, ${ }^{165}$ the heightened standard advanced above should be embodied in a statutory authorization for courts to determine whether a condemnor has made the requisite showing of paramount importance. ${ }^{168} \mathrm{~A}$ determination of this magnitude should

160 See id. at 103.

161 Id.

162 Village of Richmond Heights v. Board of County Comm'rs, 112 Ohio App. 272, 287-88, 166 N.E.2d 143, 154 (1960) (Guernsey, J., dissenting in part), appeal dismissed per curiam, 171 Ohio St. 449, 172 N.E.2d 133 (1961).

163 See supra notes $22-24$ and accompanying text.

164 Louisiana Power \& Light Co. v. Gity of Houma, 229 So. 2d 202, 212 (La. Ct. App.), cert. denied, 254 La. 1165, 229 So. 2d 350 (1969).

16s See supra notes $130-35$ and accompanying text.

${ }^{168}$ As the Virginia Supreme Court of Appeals stated:

Two cases decided by the Supreme Court of Washington illustrate the necessity of statutory authority to enable a court to determine, upon the basis of the greater public benefit, the relative rights of competing condemnors. In City of Chehalis v. City of Centralia, . . . 77 Wash. 673, 138 P. 293 (1914), the court applied the rule of first in time, first in right; but 
derive from a statutory directive rather than from a potentially strained finding of legislative authorization of the acquisition by "necessary implication."167 One commentator has observed that the judicial function of ensuring that the "best use" of the land prevails "should not be exercised under the veil of statutory construction to determine the legislative intent."188 To the extent that a legislature can resolve in advance the question of which purposes constitute the more necessary use, these conclusions should be embodied in the statute in the form of a hierarchy of certain designated uses. ${ }^{169}$

\section{The Nature of "Public Use" and the Character of the Condemnor and Condemnee}

The "occupation"-"social utility" accommodation principle also furnishes guidance for judicial construction of the term "public use" and judicial attribution of significance to the character of condemnor and condemnee. These two themes in prior public use adjudication converge when courts formalistically construe "public use" as erecting a threshold requirement that the resisting land owner possess a power of condemnation equivalent to that of the condemnor in order to be entitled to invoke the prior public use doctrine. ${ }^{170}$ In Texas Eastern Trans-

in State ex rel. Kennewick Irr. Dist. v. Superior Court for Walla Walla County, 118 Wash. 517, 204 P. 1 (1922), the court decided in favor of the condemnor who had proved that its condemnation of the property would result in the greater public benefit. The statutes governing the condemnation proceeding in Chehalis contained no provision authorizing the court to weigh the public benefit; but when Kennewick was decided, the governing statutes had been amended so as to provide: "In condemnation proceedings the court shall determine what use will be for the greatest public benefit, and that use shall be deemed a superior one."

Board of Supervisors v. Board of County Supervisors, 206 Va. 730, 735-36, 146 S.E.2d 234, 239 (1966).

${ }^{167}$ See supra notes 65-71 and accompanying text.

${ }_{168}$ Note, Intergovernmental Conflicts, supra note 70, at 210.

169 See Dau, supra note 3, at 1525-26 ("This legislative determination of the purposes fulfilling the requirement that the taking be for a more necessary public use provides certainty in this area of the law . . . I It also seems more fitting to have the legislature determine which uses shall be more necessary . . .."). Although this Comment questions the particular legislative determination at issue in People ex rel. Public Utilities Commission v. City of Fresno, 254 Cal. App. 2d 76, 81-85, 62 Cal. Rptr. 79, 82-85 (1967) (construing a California statute that defines condemnation by the state or any political subdivision as a "more necessary use" than any existing public use by a private person or a corporation), that case involves an example of the type of statutory provision discussed in the text.

${ }_{170}$ See Board of Educ. v. Pace College, 27 A.D.2d 87, 89-91, 276 N.Y.S.2d 162, 164-66 (1966), motion denied, 19 N.Y.2d 672, 225 N.E.2d 554, 278 N.Y.S.2d 862 (1967); see also supra notes 43-47 and accompanying text (discussing Pace College); supra notes 81-83 and accompanying text (discussing the significance of the character of the condemnor and the condemnee). 
mission Corp. v. Wildlife Preserves, Inc., ${ }^{171}$ the New Jersey Supreme Court adhered to such a bright line requirement. ${ }^{172}$ In that case, a pipeline and natural gas company sought to condemn, for installation of an underground gas transmission pipeline, a right of way across the land of a private, nonprofit corporation devoted to the conservation of wildlife. ${ }^{173}$ Even as the court espoused the formalistic approach, however, it implicitly acknowledged its limitations:

Defendant's voluntary consecration of its lands as a wildlife preserve, while not giving it the cloak of a public utility, does invest it with a special and unique status. Qualitatively, for purposes of the present type of proceeding, the status might be described as lower than that of a public utility but higher than that of an ordinary owner who puts his land to conventional use. Unquestionably, conservation of natural resources can and would become a legitimate public purpose if engaged in by a federal or state government or an authorized agency thereof. . . . Under the circumstances, and although plaintiff's right to condemn land in this area for the pipeline is clear, we believe . . . that Wildlife Preserves is entitled to have a plenary trial of its claim that a satisfactory alternate route is available to plaintiff which will not result in such irreparable damage to the preserve. ${ }^{174}$

As one of the attorneys for Wildlife Preserves has observed, "[t]his was not dictum, but . . . it was not intended to have any practical application."175 The jurisprudence advocated by this Comment, emphasizing judicial cognizance of possessory rights and social value, corrects the "double vision" that hindered the Wildlife Preserves court. The formalistic requirement that the condemnee and condemnor possess equivalent powers of condemnation in order to trigger the prior public use doctrine should be abandoned, because it serves neither of the policy justifications constituting the best rationale for the doctrine. Cases in which the resisting land owner enjoys "special and unique status" should be resolved in favor of applying the doctrine, ${ }^{176}$ modified, of

17148 N.J. 261, 225 A.2d 130 (1966).

172 See id. at 267-68, 225 A.2d at 134.

17 See id. at 265-66, 225 A.2d at 132-33.

174 Id. at 268,225 A.2d at 134.

17s McCarter, supra note 34, at 1079. The pipeline was later built through the wildlife refuge. See $i d$. at 1076 .

${ }^{176}$ See $i d$. at 1080 ("It can only be hoped that other jurisdictions will not adopt the needlessly narrow construction of the prior public use defense-that it is unavailable unless a mutual power of eminent domain exists."). This jurisprudence would have rendered the defense accessible to Pace College in its legal battle with the local board of 
course, by the paramount importance test outlined above.

Similarly, this jurisprudence does not align itself with courts that attribute great significance to the character of the condemnor and condemnee when a municipal corporation seeks to condemn the facilities of a public service corporation or an agent of the state seeks to condemn land devoted to public use. Rather, it aligns itself with those courts and opinions that attribute greater significance to possessory rights. ${ }^{\mathbf{1 7 7}}$ When, for example, a municipality annexes territory encompassing a public service corporation and wishes to condemn its facilities in order to take over their operation, ${ }^{178}$ this Comment contemplates no place for the assumption of "municipal, ergo more necessary." Nor do generalizations about the "low-grade" nature of public service corporations and superiority of municipalities ${ }^{179}$ suffice to allow the taking. Rather, on the facts of each case, a municipality must carry the burden of establishing paramount importance in order to overcome the protection afforded by the prior public use doctrine: "To hold otherwise would amount simply to the taking of property from one and destroying his right to operate although expressly authorized to do so, and giving it to another without any benefit to the public."180 As a certificate of public convenience is indeed a property right, it is surely entitled to protection by the courts. ${ }^{181}$ Similarly, when a political subdivision seeks to con-

education. See supra notes 43-47 and accompanying text. As indicated in the text, the "possessory rights" tilt would not necessarily act alone in compelling accessibility of the defense, but would often be reinforced by considerations of utility. As one judge put it:

I am loath to adopt the absolutist stand ... that in no case do we have power to weigh the public benefit of the proposed use against the present use of the property, merely because the condemnee lacks the power of eminent domain. It is undisputed that we can and must do so if both condemnor and condemnee have the power of eminent domain. . . .

... While in the instant case I agree that upon the facts the claim of Pace College is subordinate to that of the local school board, I would be unwilling to arrive at the same result were this taking to be of substantial portions of college campuses actually in operation, so as to interfere with such private colleges in our State as Vassar, Columbia, New York University, Cornell, or any of the other institutions of higher learning which are so essential to the public needs of our State, and indeed of the nation.

Board of Educ. v. Pace College, 27 A.D.2d 87, 92, 276 N.Y.S.2d 162, 167 (1966) (Benjamin, J., concurring in the result), motion denied, 19 N.Y.2d 672, 225 N.E.2d 554, 278 N.Y.S.2d 862 (1967).

177 See supra notes 81-105 and accompanying text.

178 See supra notes 83-97 and accompanying text.

179 See Duck River Elec. Membership Corp. v. Gity of Manchester, 529 S.W.2d 202, 206 (Tenn. 1975) ("[These corporations] are manifestly low-grade, volunteer public service type corporations, inferior in all respects, to municipalities which exist for the purpose of general government.").

${ }_{180}$ City of Pryor Creek v. Public Serv. Co., 536 P.2d 343, 346 (Okla. 1975).

181 See Town of Culpeper v. Virginia Elec. \& Power Co., 215 Va. 189, 193-94,

207 S.E.2d 864, 867-68 (1974). 
demn the land of a public service corporation and put it to a different use, there is no reason for "relaxing" the protection of the doctrine. ${ }^{\mathbf{1 8 2}}$ Rather, a municipal corporation endowed with the power of eminent domain stands no differently before the courts than a private corporation clothed with the same power. ${ }^{183}$ Finally, the jurisprudence suggested by this Comment does not sanction a futile judicial attempt to divine whether the condemnor is acting on behalf of the sovereign in order to determine whether the prior public use doctrine is operative. ${ }^{\mathbf{1 8 4}}$ Such elaborate jurisdictional gymnastics are far removed from both the "social utility" and "occupation" elements of prior public use adjudication:

We cannot see any reason for implying an overriding priority on such a theory ... . The public use of land by a private utility for water, light, and communication might appear to many persons to be of as great, if not greater, public concern and interest than that of some other governmental uses which might be asked in the name of the sovereign state. ${ }^{185}$

As another judge put it:

[I]t is begging the question ... to say that the Highway Department is the State . . . The State legislature invested the Highway Department with the power to take private property for a public use by eminent domain ... in the same degree and only to the extent it did this railroad.

... A reference to the legislative Acts which confer upon the Department the right to take property . . . shows that they simply delegated that power to the department 188

The approach to this issue adopted by the Texas Court of Civil Appeals in State v. City of Denton ${ }^{187}$ was a sound one. The state had brought an action against the city on behalf of North Texas State Uni-

182 See supra notes 98-100 and accompanying text.

183 See Vermont Hydro-Elec. Corp. v. Dunn, 95 Vt. 144, 153, 112 A. 223, 227 (1921).

184 See supra notes 101-04 and accompanying text.

185 Cemetery Co. v. Warren School Township, 236 Ind. 171, 186, 139 N.E.2d 538,545 (1957).

${ }^{188}$ Southern Ry. v. State Highway Dep't, 219 Ga. 435, 442-44, 134 S.E.2d 12, 17-18 (1963) (Duckworth, C.J., partially concurring in judgment, partially dissenting in judgment, and dissenting in opinion).

${ }_{187} 542$ S.W.2d 224 (Tex. Civ. App. 1976). 
versity to establish the right of the university to use certain public streets for a recreation center. ${ }^{188}$ The state argued that the university was an arm of the sovereign and therefore had the power to condemn public property. ${ }^{189}$ The court reviewed the relevant statutes and concluded that no statute had granted express authority to the university to condemn the streets. ${ }^{190}$ Without such authorization, the city's exclusive dominion over the streets, granted by the state legislature, had not been modified. ${ }^{191}$ Indeed, "[ $\left.t\right]$ here is no sound reason for holding state agencies . . . to a different standard from political subdivisions and nongovernmental bodies. The basic argument in favor of substantial review when other than the legislature takes applies to all grantees of a general power."182

\section{CoNCLuSION}

It is the feature of substantial review that constitutes the core value of the prior public use doctrine. When private property is condemned, judicial review is limited to monitoring for abuse of discretion, but the context of prior public use implicates a much fuller, more active judicial role. As the court in Township of Weehawken v. Erie Railroad Co. ${ }^{193}$ stated:

It was argued below . . . that Weehawken, having the power of condemnation to achieve the intended purpose, has complete discretion in determining the quantity and location of the property to be acquired, and the exercise thereof will not be disturbed absent an abuse of the power. While this is the judicial approach to the exercise of the eminent domain power, it is not applicable where the doctrine of prior use comes into play. ${ }^{194}$

When the doctrine "comes into play," courts may exploit their factfinding expertise to determine whether the condemned property is being used; whether the use is a public use; whether the proposed and pre-existing uses are compatible; and whether the proposed use is a more necessary use. If courts adopt a "judicial approach" to the "toils"

188 See id. at 225.

189 See id.

190 See id. at 229.

191 See id.

192 Note, Intergovernmental Conflicts, supra note 70, at 210; see also supra note 104 and accompanying text (discussing whether the prior public use doctrine should apply when the state delegates to an agent its power of eminent domain).

19320 N.J. 572, 120 A.2d 593 (1956).

194 Id. at 584-85, 120 A.2d at 599 (citations omitted). 
[Vol. 137:233

of prior public use litigation that mobilizes their competence to respond to both the "social utility" and "occupation" dimensions of the problem, this principle will reconcile the discrepancies in application of the prior public use doctrine. 